\title{
Grody jako instytucje władzy w monarchii wczesnopiastowskiej (w źródłach pisanych)
}

Słowa kluczowe: grody, Polska, historia, monarchia, 10-12 w.

Keywords: strongholds, Poland, history, monarchy, $10^{\text {th }}-12^{\text {th }}$ c. AD

\begin{abstract}
Paper summarizes selected source information concerning strongholds as power institutions of Polish monarchy in $10^{\text {th }}-12^{\text {th }} \mathrm{c}$. AD: forged foundation diploma for Mogilno Benedictine abbey (with date 1065), papal bullae for Gniezno, Włocławek, Wrocław and Kraków dioceses, and relevant fragments of Gallus Anonymus and Magister Vincentius chronicles.
\end{abstract}

\section{Wprowadzenie}

Dla potrzeb artykułu ograniczono się do omówienia wzmianek kilku znaczących źródeł, które dają pewien wgląd w to, jak mogły funkcjonować grody monarchii wczesnopiastowskiej w systemie władzy: kroniki Galla Anonima, częściowo kroniki Wincentego Kadłubka, falsyfikatu mogileńskiego z datą 1065 r., bulli gnieźnieńskiej, bulli kujawskiej, bulli wrocławskiej, niektórych pomniejszych uposażeń instytucji kościelnych. Cezurę wyznaczmy na ostatnie dekady XII w., gdy doszło do dekompozycji rządów opartych o statut Bolesława Krzywoustego.

Poza funkcjami zarządu militarnego, grody we wczesnych wzmiankach dyplomatycznych jawią się jako ogniwa organizacji fiskalnej (i prawdopodobnie także jurysdykcyjnej). Źródła narracyjne wskazują związek symboliczny grodów z władzą (jako demonstrację jej sprawowania) i realny: uchwycenie panowania nad grodem jest nie tylko oznaką, ale i praktycznym objęciem władzy. 


\section{Zapisy uposażeń instytutów kościelnych}

W odnotowanych w XII w. uposażeniach kościelnych, które można odnieść do funkcji organizacji grodowej, należy wskazać generalnie odmienny od źródeł narracyjnych zakres danych, które te dokumenty przenoszą: ich przedmiotem nie jest struktura władcza związana z grodami, ale należności, jakie uposażony instytut kościelny ma z nich uzyskiwać. Oznacza to, że samo odnotowanie uposażenia nie daje nam satysfakcjonującego wglądu w ustrój i uprawnienia zarządu grodowego; przy ostrożnym zastosowaniu retrospekcji można wszelako wyznaczyć pewne zakresy działania organizacji grodowej. Zapisy uposażeń ujawniają pewne wspólne cechy co możliwe, iż jest wynikiem uogólnionej praktyki kancelaryjnej, jak również najwyraźniej wynika z pewnego wzorca świadczeń i danin, z których uiszczano należności dla instytutów kościelnych.

\section{Falsyfikat mogileński}

Zawartość falsyfikatu mogileńskiego z datą 1065 r. ${ }^{1}$ mogłaby nieść pewną liczbę wskazówek odnośnie do charakteru władztwa związanego z wymienionymi tam grodami, wszelako należy zważyć względnie późną redakcję owego tekstu (najwyraźniej koniec XIII w.). Fakt ten powoduje, że liczba warstw informacyjnych dokumentu jest znaczna i niełatwa do oddzielenia (tu można tę kwestię potraktować jedynie przeglądowo ${ }^{2}$ ). Zasięg terytorialny wzmianek o grodach (i cłach rzecznych) zbiega

1 Kodeks dyplomatyczny Wielkopolski obejmujacy dokumenta tak już drukowane, jak dotąd nie ogłoszone sięgające do roku 1400, (dalej KdW) t. IV, wyd. I. Zakrzewski, Poznań 1881, nr 3.

2 J. Dobosz, Monarchia i możni wobec Kościoła w Polsce do początku XIII wieku, Poznań 2002, s. 140-147, 188-191, 193, 346-347; J. Powierski, Prusowie, Mazowsze i sprowadzenie Krzyżaków do Polski, Malbork 1996, t. 1, s. 105-189; G. Labuda, Początki klasztoru w świetle źródeł pisanych, [w: ] Materiaty sprawozdawcze z badań zespołu pobenedyktyńskiego w Mogilnie, zesz. 1, Warszawa 1978, s. 21-59; J. Płocha, Najdawniejsze dzieje opactwa benedyktynów w Mogilnie, Wrocław 1969; Z. Kürbisówna, Najstarsze dokumenty opactwa benedyktynów w Mogilnie (XI-XII w.), Studia Źródłoznawcze-Commentationes 13 (1968), s. 27-61; Z. Kozłowska-Budkowa, Repertorjum polskich dokumentów doby piastowskiej. Zeszyt I do końca wieku XII, Kraków 2006, wyd. 2 (dalej: Repertorjum), nr 8, s. 60-62, nr 15, s. 71-73; K. Buczek, Gospodarcze funkcje organizacji grodowej w Polsce wczesnofeudalnej (wiek X-XIII), [w:] Studia z dziejów ustroju społeczno-gospodarczego Polski piastowskiej, wyd. W. Bukowski, t. 3, Kraków - Warszawa 2010, s. 181-182; T. Lalik, Organizacja grodowo-prowincjonalna w Polsce XI i początków XII wieku, [w: ] Studia średniowieczne, wyb. S. Trawkowski, Warszawa 2006, s. 381-416 [pierwodruk: Studia z dziejów osadnictwa 5 (1967)], s. 391-392, 394-396, 408-409. 
się z obszarem władztwa Bolesława Kędzierzawego, co koresponduje z kompozycją listy świadków falsyfikatu ${ }^{3}$, jednakże może odpowiadać także władztwu Bolesława Szczodrego. Za tym ostatnim przemawiałyby również pewna komplementarność mazowieckiego uposażenia klasztoru w dziewięciny ze znanym kształtem uposażenia diecezji płockiej. Przedmiot i forma mazowieckiego uposażenia - tj. dziewięcin i wyliczenie ich (oprócz pieniędzy i dochodów z targów) w naturaliach (świniach, źrebiętach, rybach) wydaje się jednak dawne - z XI w., czy już z XII w., gdy książęca gospodarka hodowlana, jak się zdaje, jeszcze funkcjonowała. Szeroki i poniekąd 'unitarny' (tj. o jednolitym charakterze dla znacznej liczby zobowiązanych do świadczenia instytucji) zakres mazowieckiego uposażenia Mogilna, wskazuje jednak na intencje fundatora, tj. obdarzenia znaczącym majątkiem na samym początku istnienia instytutu, a niekoniecznie kolatora. Lista wymienionych grodów również wydaje się stara: wiele z nich nie występuje w późniejszych źródłach. Tak szerokie nadanie dziewięcin wskazuje, że dziesięciny z wymienionych wpływów były już wypłacane właściwym uprawnionym instytutom kościelnym, natomiast nie istniały inne, wcześniejsze od Mogilna fundacje, które w poborze dziewięciny (tj. drugiej dziesięciny) z wymienionych mazowieckich grodów, mogły je wyprzedzić (chyba, że benedyktyni weszli w prawa uprzednio istniejącego instytutu) - a jeżeli tak, to otrzymywały dziewięciny z innych grodów i targów. W tym ostatnim przypadku zapewne lista uposażenia klasztoru mogilskiego byłaby bardziej 'dziurawa'. Kieruje to intuicję badacza raczej ku stuleciu XI, i istotnie pozwala sądzić, że data falsyfikatu, r. 1065, jakkolwiek możliwe, że urobiona przez redaktora (bądź redaktorów) kompilacji (choć również mogąca być wynikiem zepsucia tekstu), nieprzypadkowo odnosi się do jedenastowiecznej metryki mazowieckiego uposażenia, wskazując na pewną perspektywę - zaledwie w ciągu pokolenia po odzyskaniu przez Kazimierza Odnowiciela Mazowsza.

Założywszy, że uposażenie Mogilna datuje się już z czasów drugiej monarchii piastowskiej, i raczej z jej początków, można zastanawiać się, czy ujawnione przez falsyfikat mogileński dane wskazują na pewne cechy zarządu grodowego w owym czasie. Jeżeli tak było, wonczas widzimy listę grodów jako niejako listę płatników wyznaczonej dziewięciny, i to także z targów oraz najwyraźniej również organizacji służebnej ${ }^{4}$. O ile pieniądze mogły wpływać ze wszelkiego rodzaju danin, względ-

3 Z. Kozłowska-Budkowa, Repertorjum, nr 8, s. 61-62, nr 15, s. 73.

4 K. Modzelewski, Organizacja gospodarcza państwa piastowskiego. X-XIII wiek, Poznań 2000, wyd. 2, s. 77-79. 
nie opłat, a także z żup sądowych, a świnie również z danin, to źrebce i ryby raczej pochodziły ze stadnin (opatrywanych przez konarów/kobylników) i z pracy służebnych rybitwów; świnie również z hodowli prowadzonej przez ludzi służebnych. Oznaczałoby to, że już wówczas komponentami władzy organizacji grodowej był zarząd fiskalny (najprawdopodobniejszy), zwierzchność nad targami, zapewne zarząd nad częścią organizacji służebnej, być może jurysdykcja (najpewniej targowa, ale nie tylko). Związek organizacji grodowej z ewentualnym zarządem nad służebnymi zajmującymi się hodowlą był zapewne funkcjonalny i podporządkowany wojskowemu charakterowi zarządu grodowego. Jeśli grody były ogniwami organizacji militarnej, to związanie z nimi (przynajmniej części) hodowli koni, jak i hodowli świń (a zapewne i bydła) oraz połowu ryb miałoby charakter celowy, tj. stworzenia zaplecza dla mobilizowanych sit $^{5}$. Jest to perspektywa równie atrakcyjna co zwodnicza, sugerująca unifikację struktury władczej - tymczasem nawet redakcja aktu podkreśla, iż przedmiotem nadania miałyby być dziewięciny de omnibus ad me pertinentibus, co wskazywałoby na rozmaitość tytułów panującego do dóbr objętych obowiązkiem dziewięcinnym. Zawartość późniejszych wzmianek o ludności służebnej w Polsce, jak i rozmaitość jej kategorii sugeruje, że służebni mogli być podporządkowani rozmaitym 'pionom' monarchii (zapewne kategorie te wzrastały razem z owymi pionami, powoływane ad hoc, a powstanie - jak sugerował K. Buczek - nierównych praw grupowych ludności służebnej mogło być wynikiem „wewnętrznej konwergencji” wzoru grupowego prawa rycerskiego ${ }^{6}$ ). Skłania to do pewnej ostrożności i wstrzymania się od generalizowania wniosków płynących z tego akurat źródła.

W przypadku ustanowienia dziewięciny z dochodów monarszych, udokumentowanej listą grodów, mamy powody przypuszczać, iż dobra te w tych właśnie ośrodkach były już uprzednio składane (niekoniecznie więc dla poboru dziewięciny urządzono by system fiskalny, względnie gospodarczy), tym bardziej, że już wcześniej odliczono od nich dziesięcinę (zatem od jakiegoś czasu już najwyraźniej funkcjonowały). Trudno sobie wyobrazić specjalne wprowadzanie świadczeń czy danin i dochodów oraz systemu je pobierającego, tylko dla obciążenia ich opłatami kościelnymi. Raczej to dziesięciny i dziewięciny nałożono na istniejące docho-

5 Por. M. Danielewski, Konary i Kobylniki. Rola i użytkowanie koni we wtadztwie Piastów, HSO 8 (2015), nr 1; tenże, Korabniki, Niewody i Rybitwy z terenu Kujaw jako osady stużebne związane z książęcym regale wodnym, RDSiG 71 (2011); K. Buczek, Organizacja stużebna w pierwszych wiekach państwa polskiego, [w:] Studia z dziejów ustroju społeczno-gospodarczego Polski piastowskiej, wyd. W. Bukowski, t. 3, Kraków - Warszawa 2010, s. 143 n. [pierwodruk: Studia Historyczne 20 (1977), z. 2 ].

6 K. Buczek, Organizacja stużebna, s. 145-147. 
dy, dodajmy: według sposobu gromadzenia owych dochodów. Odpowiada to nie tyle urządzaniu struktur grodowych i związanego z nimi aparatu fiskalnego, a może i służebnego, tylko nałożeniu się na organizację świeckiej struktury władczej etapu recepcji reformy gregoriańskiej, istotnie, jak się zdaje, związanego z rządami Bolesława Szczodrego. Już Karol Modzelewski zauważył, że model poboru dziesięcin z rozmaitych dóbr znika, gdy instytuty kościelne zaczynają pobierać je same - co przemawiałoby za archaiczną metryką tego typu uposażeń oraz specyficznym źródłem objętych dziesięcinami czy dziewięcinami dóbr (w tym wypadku komór panującego ${ }^{7}$ ). Wspólny dla nich byłby jednak tylko tery torialny schemat ich naliczania, wymowa źródła nakazuje nam bowiem redukcję wniosków co do ich pochodzenia, poboru i dystrybucji (w ostatnim przypadku poza należnościami dla Kościoła). Projekcja późniejszych wiadomości o kształcie uprawnień i własności monarchii na postulowany czas pochodzenia uprawnień dziewięcinnych klasztoru mogileńskiego, dawałaby powody do przypuszczeń, że już w XI w. zaistniały w organizacji grodowej momenty fiskalne, gospodarcze i jurysdykcyjne, będące źródłem objętych dziewięcinami dochodów. Nie można jednak stwierdzić, na ile organizacja ta była zunifikowana, jakie jej komponenty (o ile nie wspólistniejące agendy) dysponowały konkretnymi z wymienionych uprawnień, itd. Wspomniana projekcja stosunków XIII w. na organizację grodową musiałaby uwzględniać, iż znane w XIII w. różne agendy zarządu książęcego mogły mieć późniejszą niż X-XII w. metrykę, bądź ich uprawnienia mogły przejść redefinicję.

\section{Bulle: gnieźnieńska, kujawska, wrocławska}

Część uposażenia, jakie widzimy w bulli gnieźnieńskiej ${ }^{8}$, jest w wielu momentach zbieżna co do charakteru z uposażeniem Mogilna ${ }^{9}$. Tak jak w falsyfikacie mogileńskim widniały cła i dziewięciny z targów, pieniądza, świń, źrebców i ryb, tak w bulli gnieźnieńskiej widzimy dziesięciny (plenarias decimationes ${ }^{10}$ ) ze zboża, miodu, że-

7 K. Modzelewski, Organizacja gospodarcza, s. 78.

$8 \mathrm{KdW}, \mathrm{t} . \mathrm{I}, \mathrm{nr} 7$ (1136).

9 Ws. bulli gnieźnieńskiej patrz J. Dobosz, Monarchia i możni, s. 91-93, 225-226, gdzie podsumowanie okoliczności wystawienia i zawartości dokumentu oraz starsza literatura; por. także K. Maleczyński, W sprawie autentyczności bulli gnieźnieńskiej z roku 1136, Wrocław 1947; Z. Kozłowska-Budkowa, Repertorjum, nr 31, s. 90-92.

10 Patrz K. Modzelewski, Organizacja gospodarcza, s. 76-85; K. Buczek, Z badań nad organizacja gospodarki, s. 206-212; M.R. Pauk, Plenariae decimationes św. Wojciecha. O ideowych funkcjach dzie- 
laza, karczm, targów, futer kunich i lisich, świń, ceł tak przy grodzie, jak i wszelkich przepraw należących do grodów. Ponownie mamy tu nałożenie ogólnego ciężaru na dochody grodów, bez wnikania, z jakich konkretnie źródeł i tytułów do owych grodów wpływają. Znów lista ośrodków grodowych jest - jak i w falsyfikacie mogileńskim - „listą płatników”, ponadto, jak zauważył K. Modzelewski, nierozróżniającą grodów pryncypialnych (Gniezno), od pomniejszych (Czestram, Łekno), czy różnego znaczenia, lecz z pewnością nie stołecznych (a niektórych zupełnie prowincjonalnych - Kalisz, Ostrów, Ląd, Nakło, Sieradz, Spicymierz, Małogoszcz, Rozprza, Łęczyca, Wolbórz [nb. podobnie jak Łekno niedługo przestał być grodem panującego], Żarnów i Skrzynno) ${ }^{11}$. Znajdujące się w bulli gnieźnieńskiej wzmianki odnoszące położenie posiadłości archidiecezji do grodów, o poborze dziesięcin z ceł zarówno tych pobieranych w samym grodzie, jak i na przeprawach należących do tego grodu, wskazują, że organizacja grodowa miała kompetencje terytorialne.

Znacząca jest wczesna wzmianka o posiadaniu Łowicza cum omni penitus iuriditione seculari, nulli preter episcopum respondere habet, która wskazuje na przekazanie tam jurysdykcji wobec poddanych. Równie ważne jest połączenie z grodami nie tylko cel, ale i karczm oraz targów jako objętych dziesięcinami - co wskazuje na ich związek fiskalno-organizacyjny z ośrodkami grodowymi.

Znacznie skromniejszy wymiar uposażenia zawarty w bulli kujawskiej ${ }^{12}$ również pokazuje w posiadaniu diecezji nie tylko dwa grody (Wolbórz i Łagów), ale i dziesięcinę z ośrodka łagowskiego (zatem eksterytorialnej diecezjalnie) - należnej zapewne $\mathrm{z}$ dochodów grodu ${ }^{13}$. Dziewięcina z pieniędzy płaconych kościołowi NMP w Sandomierzu secundum polonicam iusticiam najwyraźniej wskazywałaby na swobodne dysponowanie dochodem z uposażenia tego kościoła przez właściciela kościoła. Wzmianka o dziesięcinach z grodu gdańskiego należnych od zboża, tak jak opłaty od okrętów, znów wskazuje na związek poboru ceł z organizacją grodową. Podobne znaczenie ma umieszczenie wśród dochodów decimam partem de moneta et de iudiciis totius episcopatus - co wskazuje na obłożenie dziesięciną bicia monety - względnie

sięciny monarszej w Polsce i na Węgrzech w XI-XII wieku, [w:] Gnieźnieńskie koronacje królewskie i ich środkowoeuropejskie konteksty, red. J. Dobosz, M. Matla, L. Wetesko, Gniezno 2011, s. 187-212.

11 K. Modzelewski, Organizacja gospodarcza, s. 108.

12 Kodex dyplomatyczny Polski obejmujący przywileje królów polskich, wielkich książąt litewskich, bulle papiezkie... (dalej KdP), wyd. L Ryszczewski, A. Muczkowski, Warszawa 1848, t. II, cz. 1, nr 1 (1148). 13 Ws. procesu fundacyjnego biskupstwa kujawskiego patrz J. Dobosz, Monarchia i możni, s. 199, 216-219, 331-332. Por. Z. Kozłowska-Budkowa, Repertorjum, nr 29, s. 88-89, nr 47, s. 108-109; K. Modzelewski, Chtopi w monarchii wczesnopiastowskiej, Wrocław 1987, s. 195-196. 
wszystkich dochodów panującego nie w naturaliach, lecz pieniądzu - oraz kar i żup sądowych pobieranych w diecezji.

Bulla wrocławska z r. $1155^{14}$ nie mówi o konkretnym uposażeniu należnym z grodów, ale wymienia je w porządku wskazującym na ogólnie zarysowaną południowo-zachodnią granicę diecezji. Jakkolwiek można by przypuszczać, że wyliczenie grodów może służyć ustaleniu pewnych świadczeń czy opłat na rzecz diecezji ${ }^{15}$, to jednak takowe (ani ich przedmiot) nie są wskazane w tekście. Pewną wskazówką jest okoliczność, że po liście grodów bulla wymienia następnie te, które dowodnie i później znajdowały się w bezpośredniej własności diecezji, tj. Otmuchów i Milicz (wraz z targiem przeniesionym z Trzebnicy do Cerekwicy) ${ }^{16}$. Może sugerować, że uprawnienia dzierżone w poprzednio wymienionych grodach miały charakter nie własnościowy, lecz dziesięcinny czy fiskalny.

Kolejny przykład ustanowienia uposażenia na dochodzie panującego widzimy w przywileju Leszka Bolesławowica ${ }^{17}$ dla diecezji kujawskiej, gdzie książę nadaje gród słoński, ale i dodatkowo 10 grzywien srebra rocznie z targu we Włocławku i dziesięć donic miodu rocznie z piwnicy w Starym Władysławiu. Natomiast bulla papieska dla diecezji krakowskiej ${ }^{18}$ nie wymienia żadnych granic, uposażeń ani własności, jakkolwiek funkcjonują pozytywne wzmianki rocznikarskie o uposażeniu katedry i diecezji19.

Uposażenie wymienione przy okazji konsekracji kościoła NMP w Sandomierzu ${ }^{20}$ wzmiankuje nie tylko kaplice w Żarnowie, Sandomierzu, Połańcu, Zawichoście oraz Sieciechowie (zatem przy grodach), ale i pewne ich niesprecyzowane dochody (cum

14 KdW t. I, nr 586/18a (1155). Nowsze wydanie: Schlesisches Urkundenbuch (dalej SUB), bearb. v. H. Appelt, I. Bd., 1. Lieferung: 971-1216, Graz-Köln 1963, nr 28, s. 19-21: In quibus hęc propriis duximus exprimenda vocabulis: civitates, Castella, villas, curtes et plebes Trecen, Tescin, Gradice Golensicezke, Otemochov, Gradice Barda, Nemechi, Gramolin, Gradicem Ztrigom, Zpini, Valan, Godiuice, Szobolezke, Glogov, Sezezko, Milice.

15 TakJ. Dobosz, Monarchia i możni, s. 93-95; por. T. Lalik, Organizacja grodowo-prowincjonalna, s. 392.

16 SUB, t. I, cz. 1, nr 28, s. 20: Hęc predicta loca singula cum omnibus pertinentiis earum, terras quoque cultas et incultas, servos ac ancillas et cetera, quę iuste et legitimie etenże ecclesie pertinent, abbatiam sancti Martini cum pertinentiis suis, castellum Otomochov cum pertinentiis, castrum Milich ad usus fratrum supradictę ecclesię deputatum cum pertinentiis suis, forum de Trebnice, quod Circuice translatum est.

17 KdP t. II, cz. 1, nr 2 (1185).

18 Kodeks dyplomatyczny katedry krakowskiej ś. Wacława, wyd. Fr. Piekosiński, (dalej KKK), Kraków 1874, cz. I, nr 3 (1186).

19 M.D. Kowalski, Uposażenie krakowskiej kapituty katedralnej w średniowieczu, Kraków 2000, s. 15-24

20 Kodeks dyplomatyczny Małopolski (dalej KMp), wyd. Fr. Piekosiński, Kraków 1876, t. I, nr 2 (1191); patrz J. Dobosz, Działalność fundacyjna Kazimierza Sprawiedliwego, Poznań 1995, s. 90-95. 
suis redditibus), za wyjątkiem kaplicy w Żarnowie cum suis redditibus et omnes decime castri eiusdem cum redditibus eisdem decimis pertinentibus - zatem $\mathrm{z}$ bardzo hojnym uposażeniem. Osobno wymieniony jest w uposażeniu Żarnów (jako villa canonicorum kolegiaty NMP w Sandomierzu) z dziewiątym i dziesiątym targiem, dziewiątą i dziesiątą karczmą oraz ze zbożem z całego okręgu grodowego [pobieranym] od ludzi książęcych.

O uposażeniu diecezji płockiej mówi notatka z data 1203 r. (lecz z pewnością zbierająca starsze informacje), wymieniająca grody, wsie i cła biskupstwa oraz kapituły $^{21}$. Należy zaznaczyć, że wymienia ona nie dziesięciny z dochodów według klucza grodów panującego, lecz grody, które znalazły się w posiadaniu Kościoła (wraz z częścią uprawnień władczych - m.in. jurysdykcją i prawem do poboru świadczeń i danin od poddanych Kościoła zamieszkałych w przekazanych okręgach grodowych) - tj. Pułtusk, Brańsk, Brok i Święck, następnie Czarnow i Ruz. Kwestie funkcjonowania kasztelanii Kościoła zostawiamy na boku, zaznaczając, że istotnie można przyjąć, iż nadania grodów (nie tylko pewnych części dochodów przy nich afiliowanych) były aktem donacji nie tylko obiektu, ale i znaczących uprawnień jurysdykcyjnych oraz fiskalnych, na co wskazuje ciągłość wykonywania tych uprawnień przez instytuty kościelne w XIII w. ${ }^{22}$

Metryka nadań grodów jest stara - występowanie ich w przywilejach XII w. tylko w dwóch przypadkach (Wolborza i Słońska) wyznacza konkretny termin ich nada-

21 I. Castellaniae Ecclesiae Plocensis. II. Telonea Ecclesiae Plocensis. III. Villae capituli Plocensis, wyd. W. Kętrzyński, Monumenta Poloniae Historica, t. 5, wyd. Lwów 1888, s. 419-443 (tekst notatki dot. grodów i wsi do nich przynależnych, s. 433-437); Zbiór ogólny przywilejów i spominków mazowieckich, wyd. J.K. Kochanowski, Warszawa 1919, nr 301 (1203).

22 Ws. tzw. kasztelanii majątkowych Kościoła patrz K. Modzelewski, Organizacja gospodarcza, s. 85-86; tenże, Między prawem książęcym a wtadztwem gruntowym, cz. I: Z zagadnień początków poddaństwa w Polsce, Przegląd Historyczny 71 (1980), nr 2, s. 209-234; tenże, Między prawem ksią̨̇̇ecym a władztwem gruntowym, cz. II: Instytucja kasztelanii majątkowych Kościoła, Przegląd Historyczny 71 (1980), nr 3, s. 449-480; tenże, Chtopi, s. 193-207; K. Buczek, Z badań nad organizacja gospodarki w Polsce wczesnofeudalnej, [w:] Studia z dziejów ustroju społeczno-gospodarczego Polski piastowskiej, wyd. W. Bukowski, t. 2, Kraków 2006, [pierwodruk: Kwartalnik Historii Kultury Materialnej 17 (1969), nr 2], s. 19-21; St. Trawkowski, „Homines ascripticii castellanie de Voybor”. W sprawie genezy kasztelanii kościelnych, [w:] Cracovia-Polonia-Europa. Studia z dziejów średniowiecza ofiarowane Jerzemu Wyrozumskiemu w sześćdziesiątą piątą rocznicę urodzin i czterdziestolecie pracy naukowej, red. W. Bukowski, Kraków 1995, s. 221-227; M.R. Pauk, E. Wółkiewicz, „Ministri enim altaris ministri curie facti sunt”. Ottońsko-salicki „system” Kościoła Rzeszy i jego oddziaływanie w Europie Środkowej XI-XII wieku, [w: ] Kościół w monarchiach Przemyślidów i Piastów. Materiały z konferencji naukowej Gniezno 21-24 września 2006 roku, red. J. Dobosz, Poznań 2009, s. 119-125, i aneks, s. 136-138. 
nia, pozostałe grody znalazły się w posiadaniu odpowiednich diecezji najprawdopodobniej dawno, niewykluczone, że w trakcie odbudowy struktur Kościoła w drugiej połowie XI w. ${ }^{23}$

Wspólny mianownik dla większości wymienionych uposażeń to obłożenie dziesięciną, a nieraz i dziewięciną, a niekiedy określonym kwotowo ciężarem, dochodów grodów, które mogły pochodzić bądź pochodziły z wielu źródeł: gospodarki hodowlanej, danin, jurysdykcji, dochodów z cel, opłat targowych czy karczemnych. Wyznacza to zakres uprawnień urzędników grodowych: pobór danin, ceł, opłat targowych i od karczm, zapewne również jurysdykcję i nadzór nad niektórymi elementami organizacji służebnej (tymi, które dawały dochód w naturaliach: świnie, źrebięta, złowione ryby). Nie można jednak szczegółowo odtworzyć ani spisu danin, które przynosiłyby te przychody, ani umiejscowienia ewentualnych wiosek służebnych; ewidentnie pobór należał do aparatu grodowego, inaczej w uposażeniu wskazano by konkretne daniny i miejscowości. Uwagę przyciągają dziesięciny i dziewięciny nałożone na cła, opłaty targowe i karczemne. Z późniejszych, trzynastowiecznych wzmianek wynikałoby, że opłaty targowe i cła były osobno w częściach pobierane przez kasztelanów i mincerzy (tj. urzędników niezależnych od administracji kasztelańskiej).

Dobra i uprawnienia ofiarowane Kościołowi musiały mieć walor trwałości, inaczej ich przekazanie nie byłoby warte obwarowania przywilejem. Czy jest to odnotowaniem ich ustanowienia? To oczywiście możliwe, ale trzeba wówczas wziąć pod uwagę niebezpieczeństwo nietrwałości i chwiejnego statusu uposażenia - ktoś musiałby te dobra (świadczenia, uprawnienia) gwarantować (więc nadal władza świecka?), a wręcz narzucać. Alienowane uprawnienia odwoływałyby się najwyraźniej do trudnego do zakwestionowania zwyczaju - czyli raczej musiałyby być ugruntowane, a jeśli zmodyfikowane, to tak, by ich uzasadnienie nie doznało uszczerbku.

\section{Źródła narracyjne: kroniki Anonima zw. Gallem i Mistrza Wincentego}

Jak w przekazie Galla rozumiana jest władza i jak wyglądają narzędzia jej wykonywania? W kronice Anonima możemy odróżnić - w wielkim skrócie i pomijając liczne pozostałe - dwie płaszczyzny relacji: opowieść o wzorze władcy - Bolesławie Chrobrym w rozdziałach 6-16 pierwszej księgi, i konkret ówczesnej „historii najnowszej”

23 Por. J. Dobosz, Monarchia i możni, s. 127 n.; H. Łowmiański, Początki Polski, t. 6, cz. 1, Warszawa 1985, s. 344-352. 
w dalszych częściach źródła. Gallowe „zwierciadło władcy” nie było przecież tylko historią ad usum delphini, fikcyjną, czerpiemy stamtąd znaczące informacje choćby na temat zjazdu gnieźnieńskiego - wszelako należy pamiętać o konstrukcji, w której zostały one umieszczone. Charakter rozdziałów 6-16 pierwszej księgi kroniki Anonima stanowi zespół zhieratyzowanych, sprowadzonych do reguł rządzących tradycją historyczną, zapisów heroicznej przeszłości, „złotego wieku”, spersonifikowanych w postaci Bolesława Chrobrego ${ }^{24}$. Pierwsza księga Kroniki (wraz z chorografią i „dziejami bajecznymi” Piastów), jakkolwiek w znacznej mierze autonomiczna, jest więc zapleczem nie tylko faktograficznym - w warstwie „historii najnowszej” - czasów Bolesława Krzywoustego, ale i tworzy środkami literackimi perspektywę ideową dla dalszych części kroniki. Tekst ten jest, jak ujął to w odniesieniu do „dziejów bajecznych” Jacek Banaszkiewicz, wykładem poglądów na temat istoty władzy królewskiej, stwierdzeniem zadań, oczekiwań i ograniczeń spoczywajacych na osobie zwierzchnika wspólnoty ${ }^{25}$. Próbując wyłuskać z kroniki Anonima wzmianki pozwa-

24 J. Banaszkiewicz, Giecz na Gallowej liście wielkich grodów Bolestawa Chrobrego, [w:] Gród piastowski w Gieczu. Geneza - Funkcja - Kontekst, red. M. Kara, T. Krysztofiak, A.M. Wyrwa, Poznań 2016, s. 75-81; tenże, Gall jako historyk poważny, czyli dlaczego dzieje i Bolesława Chrobrego, i Bolesława Krzywoustego sa prawdziwe i niegroteskowe, [w: ] Takie sobie średniowieczne bajeczki, Kraków 2013 (wyd. 2), s. 572-576 [pierwodruk: Przegląd Historyczny 99 (2008), nr 3]; E. Skibiński, Przemiany wtadzy. Narracyjna koncepcja Anonima tzw. Galla i jej podstawy, Poznań 2009, s. 226-236; por także m.in. Cz. Deptuła, Galla Anonima mit genezy Polski. Studium z dziejów historiozofii i hermeneutyki symboli dziejopisarstwa średniowiecznego, Lublin 2000, s. 74-75, 335-336, 337n.; W. Wójtowicz, Konstruowanie Galla. Problem oralności jako problem interpretacyjny tekstu, Litteraria Copernicana 19 (2016), nr 3, s. 121-122; D. Bagi, Die Darstellung der Zusammenkunft von Otto III. und Bolesław dem Tapferen in Gnesen im Jahre 1000 beim Gallus Anonymus. Ein Interpretationsversuch, [w: ] Die ungarische Staatsbildung und Ostmitteleuropa, hrsg. von F. Glatz, Budapest 2002 [Begegnungen - Schriftenreihe des Europa-Institutes Budapest, Bd. 15], s. 177-188, http://www.europainstitut.hu/index.php/ publikationen/begegnungen/17-begegnungen/532-begegnungen15bagi, [dost. 31 XII 2017]: Für den Gallus Anonymus soll also das Zeitalter von Bolestaw dem Tapferen von außerordentlicher Wichtigkeit gewesen sein, er bedeutet für ihn den neuen Beginn nach der heidnischen Episode, den Beginn der christlichen Geschichte von Polen; patrz P. Wiszewski, Domus Bolezlai. W poszukiwaniu tradycji dynastycznej Piastów (do około 1138 roku), Wrocław 2008, s. 11; przegląd źródeł rysujący perspektywę porównawczą dla r. 6-16 ks. I kroniki Anonima por. W. Fałkowski, Karolińskie zwierciadto władcy - powstanie gatunku, [w:] Europa barbarica, Europa christiana. Studia mediaevalia Carolo Modzelewski dedicata, red. R. Michałowski, Warszawa 2008, s. 59-74, a także R. Antonin, Ideální panovník českého středověku. Kulturnè-historická skica z dèjin středověkého myšlení, Praha 2013, s. 11-39, 48-54, 57-79.

25 J. Banaszkiewicz, Podanie o Piaście i Popielu. Studium porównawcze nad wczesnośredniowiecznymi tradycjami dynastycznymi, Warszawa 1986, s. 24; por. także Cz. Deptuła, Galla Anonima mit, s. 298-300, 322-325, 333-336; W. Polak, Gesta Gallowe a kultura oralna, [w:] Tekst. Źródła. Krytyka, Interpretacja, red. B. Trelińska, Warszawa 2005, s. 66; w ostatnim - z założenia skrótowym - ujęciu 
lające na wywiedzenie wniosków na temat struktur monarchii wczesnopiastowskiej i ich funkcji, należy mieć na uwadze nie tylko to, że nie była ona spisana po to, by te struktury na użytek dzisiejszego historyka opisywać, lecz również i to, że zabiegi, by z zapisu tradycji historycznejej (jakim z pewnością w istotnych jej częściach jest ta kronika), wydobyć „pierwotny rdzeń” zdarzeń i ich okoliczności, są, niestety, raczej wyrazem prób pogodzenia pozytywistycznego odrzucenia zapisów niesprawdzalnych (przynajmniej wedle reguł warsztatu nastawionego na ustalanie faktów „wie es eigentlich gewesen war"), i romantycznej ich akceptacji ${ }^{27}$. Rozbiór tekstu tak, by pewne jego partie akceptować jako 'wiarogodne', a inne jako 'fabrykaty', pomija współczesną jego funkcję i zasady tworzenia, nie pozwala na odczytywanie faktów kulturowych, nieraz decydujących o przekazie, funkcji oraz oddziaływaniu badanego tekstu $^{28}$. W tym wypadku oznacza to, że raczej należałoby próbować znaleźć relację między opisywanymi w kronice funkcjami i strukturami zarządu monarchii a funkcją samego tekstu, by móc w ogóle zbliżyć się do ewentualnego modelu rządów. Pierwszeństwo będzie miała jednak funkcja tekstu. Wzmianki o zarządzie monarchii w kronice Anonima należałoby raczej traktować jako fenomeny, które znalazły się w tekście niejako w charakterze dekoracji scenicznej, kontekstu - dla wywodu, który czy to z przyczyn konstrukcyjnych, czy to dla przekazywanych wartości nie

krytycznym roli pierwszej księgi kroniki w stosunku do reszty dzieła, E. Skibiński pomija to zagadnienie: E. Skibiński, Kronika Galla w świetle poetyki. Uwagi wstępne, [w: ] Nobis operique favete. Studia nad Gallem Anonimem, red. A. Dąbrówka, E. Skibiński, W. Wojtowicz, Warszawa 2017, s. 238-240, por. s. 367-368 (E. Skibiński, głos w dyskusji), por. także P. Wiszewski, Dlaczego jedna kronika? O nieunitarystyczną analize genezy dzieła Anonima, tamże, s. 211-222, por. s. 372-374 (P. Wiszewski, głos w dyskusji). Nb. w pierwszej księdze kroniki widać pewne prefiguracje odnoszące się nie tylko do postaci władców, por. wizerunek Miecława: Anonima tzw. Galla kronika czyli dzieje książat i wtadców polskich, wyd. K. Maleczyński, Kraków 1952, Monumenta Poloniae Historica Series Nova (dalej MPH SN) t. 2, (dalej Anonim), ks. I, r. 20, s. 45, poprzedzający charakterystykę Sieciecha (Anonim, ks. II, r. 4, s. 68); ws. licznych nawiązań - także antytetycznych - między przedstawieniami z ks. I kroniki a następnymi zob. W. Wójtowicz, Konstruowanie Galla, s. 122-126, tamże dalsza literatura.

26 Fr. Graus, Živá minulost. Středovèké tradice a představy o středověku, Praha 2017, przekład z niem. pierwodruku: Lebendige Vergangenheit. Überlieferung im Mittelalter und in den Vorstellungen vom Mittelalter, Wien 1975, przekł. J. Dobeš, s. 16.

27 Fr. Graus, Živá minulost, s. 17-18; por. uwagi St. Kwiatkowskiego o 'modernizmie historiograficznym', Pamięć elit jako świadectwo o rozporzadzeniu sukcesyjnym Bolestawa Krzywoustego z 1138 roku, [w:] Stilo et animo. Prace historyczne ofiarowane Profesorowi Tomaszowi Jasińskiemu w 65 rocznicę urodzin, red. M. Dorna, M. Matla, M. Sosnowski, E. Syska, Poznań 2016, s. 131-132.

28 J. Banaszkiewicz, Podanie o Piaście i Popielu, s. 11-12; por. także Cz. Deptuła, Galla Anonima mit, s. 28-32, 49-51; P. Wiszewski, Domus Boleslai, s. 131-134; E. Skibiński, Narracja, s. 237-239. 
mógł się na nich ogniskować. Nie tworzą one jednak rdzenia faktów kulturowych, które kronikarz chciałby opisać. Nie oznacza to, że należy uznać Gallową faktografię za wyłącznie funkcję narracji, a nawet ją negować - raczej skłania to do ostrożności przy literalnym odczytywaniu tych jego wzmianek, które można by odnieść do szczegółowych kwestii zarządu monarchii. Trudno wszakże odstąpić w ogóle od prób rekonstruowania wydarzeń i okoliczności na podstawie kroniki - tekstu, który z założenia o wydarzeniach i ich okolicznościach mówi. Chciałbym zwrócić uwagę na te wzmianki, które mówią o zarządzie grodów i nominacjach, z kilkoma wyjątkami tyczącymi kontekstu militarnego.

Relacja Anonima o liczbie rycerzy obleczonych w kolczugi i tych, którzy chronili się tarczami, a których Bolesław Chrobry miał w Poznaniu, Gnieźnie, Gieczu i Włocławku, należy do 'zwierciadła władcy', wszakże charakter danych skłania do zastanowienia ${ }^{29}$. Liczby rycerzy z wymienionych grodów są z jednej strony nazbyt „okrągfe” (co nota bene w zasadniczy sposób podważa ich literalną wiarygodność), by oddawać jakowyś szczegółowy spis, z drugiej strony reprezentują specyficzne wartości - najwyraźniej jako pewne proporcje, z których te między 'potencjałami' wymienionych grodów mogą być, w mojej opinii, wiarygodne. Liczby de aliis civitatibus et castellis zostały pominięte typowym dla Galla omówieniem jego niewiedzy (et nobis longus et infinitus labor est enarrare, et vobis forsitan fastidiosum fuerit hoc audire). Ten ostatni zabieg, dość dla Anonima typowy, jest nota bene sugestią dużej liczby innych grodów, a także najwyraźniej identycznego (jak Gall zapewne przyjmował i być może zakładał, że i jego odbiorcy przyjmują, o ile właśnie oni tego nie zaznaczyli) wzorca 'mobilizacji' w przypadku mniej prominentnych grodów. Jest to również usprawiedliwienie się z pominięcia innych grodów, które wszelako zgodnie z najlepszą wiedzą współczesnych albo były równie znaczące (ale leżały poza Wielkopolską i Kujawami), albo były mniej znaczące - choćby w Wielkopolsce leżały i mogły za-

29 Anonim, ks. I, r. 2, s. 25-26; patrz ostatnio: J. Banaszkiewicz, Giecz, s. 82-89; P. Żmudzki, Wtadca i wojownicy. Narracje o wodzach, drużynie i wojnach w najdawniejszej historiografii Polski i Rusi, Wrocław 2009, s. 354-362; T. Jurek, Die Entstehung des polnischen Adels, [w:] Studien zum Adel im mittelalterlichen Polen, hrgb. v. E. Mühle, Wiesbaden 2012, s. 22 [pierwodruk: Geneza szlachty polskiej, [w:] Šlechta, moc a reprezentace ve středověku, wyd. M. Nodl., M. Wihoda, Praha 2007]; R. Barnat, Sity zbrojne Bolesława Chrobrego w świetle relacji Galla Anonima, Przegląd Historyczny 88 (1997), z. 2, s. 222-235; M. Bogacki, Przemiany w wojskowości polskiej od połowy X wieku do 1138 roku. Ksztatt i organizacja armii, Toruń 2007, s. 178-189; por. także: Z. Dalewski, Władza, przestrzeń, ceremoniał. Miejsce i uroczystość inauguracji władcy w Polsce średniowiecznej do końca XIV w., Warszawa 1996, s. 11-12. K. Buczek, Organizacja stużebna, s. 143-144; tenże, Targi i miasta na prawie polskim (Okres wczesnośredniowieczny), Wrocław - Kraków 1964, s. 111. 
sługiwać na wymienienie choćby z racji bliskości terytorialnej. Natychmiast jednak sam kronikarz śpieszy z wyjaśnieniem, które niejako anuluje przyczynę wymieniania jakichkolwiek liczb: sed ut vobis numerandi pretermittam numerum vobis sine numero multitudinis anteponam. Plures namque habebat rex Bolezlaus milites loricatos, quam habet nostro tempore tota Polonia clipeatos; tempore Bolezlaui totidem in Polonia fere milites habebantur, quot homines cuiusque generis nostro tempore continentur. Tak ten fragment, jak i podkreślanie przez Anonima, że chodzi - bez względu na uzbrojenie (i tym samym status materialny) - o rycerzy, wskazuje, że w jego zamyśle liczby te nie dotyczyły chłopskiego pospolitego ruszenia. Zasadniczym powodem jest zatem nie tyle sporządzenie jakiegoś wykazu, ale zademonstrowanie potęgi Bolesława i jego władztwa - wykraczającej poza stosunki kronikarzowi (i jego odbiorcom) współczesne. Raczej nie można uznać, by ów 'popis wojska’ mógł dotyczyć drużyny królewskiej i jej organizacji - nie tylko ze względu na to, iż wymienieni są tu rycerze rozlokowani według grodów, tj. nie mogący być ciągle u boku władcy, ale i z uwagi na obecność wojów wyposażonych w tarcze, a zatem pośledniejszych, nie mogących należeć do grona towarzyszy władcy, jak i ze względu na okoliczność, iż nie znajdujemy w tym opisie określeń wskazujących na szczególne relacje Bolesława Chrobrego z tymi właśnie rycerzami ${ }^{30}$. Użyte liczby i dobór grodów skłaniają jednak do zastanowienia.

Gall mógłby bez obawy wskazać również inne dobrze sobie znane główne grody monarchii, choćby Kraków, Wrocław, Sandomierz, jednak tego nie zrobił. Klucz terytorialny i wymienienie według niego znacznych grodów świadczyłyby o tym, że raczej przekazał i przetworzył pewne dane, niż je całkiem wymyślił. Wydawca przekładu wątpił, by mogła je przekazać tradycja ustna ${ }^{31}$. Należałoby zwrócić uwagę na okoliczność, iż Gall miał dostęp do źródeł zaginionych ${ }^{32}$. Można ze wszelkimi zastrzeżeniami co do ewentualnej wadliwości i braku konkretnej podstawy źródłowej takiego poglądu przypuścić, że Gall mógł zapoznać się z obliczeniami wysokości zobowiązań militarnych Polski wobec cesarstwa sprzed 1000 r. Wówczas, jak pisze

\footnotetext{
30 Przeciwnie z uwzględnieniem zróżnicowanych argumentów M. Bogacki, Przemiany, s. 187-189.

31 Anonim tzw. Gall. Kronika Polska, przeł. R. Grodecki, opr. M. Plezia, Wrocław - Warszawa Kraków 1996, wyd. 7, Seria I Biblioteki Narodowej, nr 59, s. 26.

32 Anonim, ks. I, r. 6, s. 18, 20; por. P. Żmudzki, Wtadca, s. 356-357; M. Bogacki, Przemiany, s. 180-182; P. Wiszewski, Domus Boleslai, s. 166-170; T. Jurek, Die Entstehung, s. 22, i przyp. 36; por. także uwagi J. Banaszkiewicza na temat przeglądu wojsk Bolesława Chrobrego podczas zjazdu gnieźnieńskiego 1000 r., J. Banaszkiewicz, Otto III jedzie do Gniezna. O oprawie ceremonialnej wizyty cesarza w kraju i stolicy Polan, [w: ] Trzy po trzy o dziesiątym wieku, Kraków 2014, s. 213-217.
} 
Thietmar, Otto III 'trybutariusza uczynił panem ${ }^{33}$; - istniał więc wtedy konkretny wymiar obowiązków Bolesława wobec cesarstwa. Pewną sugestią jest tutaj liczba 300 obleczonych w kolczugi rycerzy, podarowanych przez Bolesława Ottonowi w 1000 r. ${ }^{34}$ Liczby zbrojnych wymienione w ks. I, r. 8 kroniki są znaczne - nie mogły to raczej być wysokości posiłków, jakie winny byłby cesarzowi Bolesław, ale raczej 'podstawa' obliczenia kontyngentu (por. - znaczną, o ile nie fantastyczną - liczbę 3000 zbrojnych Mieszka, przekazaną przez Ibrahima ibn Jakuba). Podkreślenia wymagają raczej nie surowe liczby wyrecytowane przez Anonima, ile stosunki między nimi. Na odbiorcach wrażenie musiała robić nie tylko sama wielkość sił, jakie stawały w gotowości z kolejnych wymienionych grodów, ale i stosunek liczby rycerzy okrytych kolczugami do tych słabiej uzbrojonych - ten zapewne również Anonim istotnie podwyższył, do proporcji ok. 1:3 (poza Gieczanami). Frapujące są jednak relacje między kolejnymi wymienionymi grodami - tutaj, nawet gdyby uznać, że same liczby rycerzy są fantastyczne, to stosunki między nimi być może oddają różnice między potencjałami mobilizacyjnymi tych grodów.

Jakkolwiek by nie próbować roztrząsać tych liczb, jest to raczej próba dopasowania inwencji Anonima do racjonalnych (z naszego punktu widzenia) ewentualnych źródeł informacji czy szacunków. Znaczące jest wskazanie czterech głównych grodów leżących w centrum monarchii Bolesława Chrobrego. Być może ograniczenie się do tych właśnie grodów wyznacza terytorialny rdzeń monarchii pierwszych Piastów - obszar, który był pod ich rządami najdłużej, gdzie ich władza była ugruntowana, skąd czerpali siły do dalszych podbojów.

Co ten omawiany fragment mówi o władzy Piastów? To władza nad siłą militarną zorganizowaną według klucza terytorialnego. Raczej nie są to załogi grodowe, ale z sowitym naddatkiem zaokrąglone przez Anonima do imponujących liczb 'zdolności mobilizacyjne’ okręgów określonych nazwami naczelnych grodów - zarazem najważniejszych osad monarchii i jej obronnych punktów. Należy wziąć pod uwagę pewną dezynwolturę, z jaką w ogóle w kronice traktowane są liczby zbrojnych. Istotniejsze jest czytelne dla współczesnych kronikarza powiązanie grody-zbrojni, ci ostatni wymienieni według klucza jakości uzbrojenia, a także dobór grodów z wielkopolsko-kujawskiego rdzenia władztwa Piastów.

33 Kronika Thietmara, tłum., wst. i przyp. M.Z. Jedlicki, posł. K. Ożóg, Kraków 2014, ks. V, r. 10, s. 99, por. s. 314-317.

34 Kronika Thietmara, ks. IV, r. 46, s. 78. 
Element ekonomicznego i terytorialnego znaczenia grodów uchwytny jest w dwóch innych rozdziałach kroniki mówiących o rządach Bolesława Chrobrego. Znacząca jest - tym razem chyba typowo „wychowawcza” - wzmianka r. 12 ks. I, o tym, jak to Bolesław suos ... rusticos non ut dominus in angariam coercebat, sed ut pius pater quiete eos vivere permittebat. Ubique enim [Ubi enim] suas staciones suumque servitium determinatum habebat, nec libenter in tentoriis sicut Numida vel in campis, sed in civitatibus et castris frequentius habitabat. Et quotiens de civitate stationem in aliam transferebat, aliis in confinio dimissis, alios vastandiones et villicos commutabat ${ }^{35}$. Ów chyba idylliczny obrazek miałby pokazywać, jak to Bolesław Chrobry wzbraniał się przed korzystaniem ze świadczeń stacyjnych, podwód itd. - ale polegał chyba wyłącznie na swych rządcach, i servitium determinatum, które, jak widać, miał in civitatibus et castellis. W dodatku owo servitium znajdowałoby się w pieczy vastandiones et villicos, rządców i włodarzy, których kompetencje byłyby w wyraźnie terytorialne.

Servitium determinatum miałoby zatem postulowany wymiar rezydencjonalny (a więc i gospodarczy), i ograniczony do grodów i ich niższej rangi personelu urzędniczego oraz zapewne na poziomie najniższym służebnego ${ }^{36}$. Warto zauważyć, że Gall podkreśla, iż ze służb owych panujący miał korzystać i w podróży poza grodem, zmieniając ich in confinio owych civitates - czyli pewnie i granicy władzy względem służby owych rządców (zamiast uciskać napotkanych chłopów). Jest to pochwała ludzkości monarchy, który, jak dalej to Gall podkreślił, nihil tamen de alienis sed de propriis in hiis omnibus expendebat ${ }^{37}$.

To, co jest istotne, to zakreślenie terytorialnego charakteru obowiązku rządców - a zatem mieliby być w konstrukcji tego fragmentu związani i z grodem, i z terytorium służbą (jak i najpewniej zakresem władzy, uprawnieniami - fiskalnymi czy gospodarczymi ${ }^{38}$ ). Łatwo stąd wyprowadzić wniosek, że Anonim widział organiczny związek między służbą panującemu, grodem i terytorium. Grody byłyby zatem jednostkami terytorialnymi, z odpowiednim personelem. Ceremonialny charakter

\footnotetext{
35 Anonim, ks. I, r. 12. s. 31-32; por. uwagi K. Modzelewskiego ws. emendacji Ubi enim na Ubique enim, tenże, Organizacja gospodarcza, s. 25.

36 Odnośnie terminu servitium determinatum i jego odniesień do znanego ze stosunków Rzeszy servitium regis i pozostałych świadczeń stacyjnych patrz zwięzły przegląd literatury: M.R. Pauk, E. Wółkiewicz, „Ministri enim altaris, s. 126-129; por. K. Modzelewski, Organizacja gospodarcza, s. 24-26, i przyp. 34, który uznał użycie określenia servitium determinatum przez Anonima za zastosowanie nie ścisłego terminu, lecz pojęcia obiegowego.

37 Anonim, ks. I, r. 14, s. 34.

38 K. Modzelewski, Organizacja gospodarcza, s. 24-30.
} 
spotkań na pograniczach osłabia jednak 'organizacyjną' wymowę tego fragmentu ${ }^{39}$. Przedstawiony wniosek dotyczy okoliczności będących w znacznym stopniu konstruktem narracyjnym ${ }^{40}$, opowiadania o różnicy między dawnymi, dobrymi czasami, a stosunkami obecnymi - niejako z perspektywy petenta, udręczonego kosztami ludzkimi i materialnymi świadczeń stacyjnych. Czyżby był to więc ukryty postulat? Nie sposób nie widzieć w tym fragmencie dalekiej zapowiedzi przywilejów z Łęczycy, Borzykowej i Wolborza ${ }^{41}$. Postulat ten utrzymany byłby jednak w normach epoki: nie jest to wezwanie do formalnego udzielenia zwolnienia od świadczeń (ani tym bardziej nie wskazuje, kto miałby być odbiorcą immunitetu), a raczej zorganizowania przez monarchię systemu konsumpcji w zakresie własnej struktury - niejako $\mathrm{z}$ własnej szczodrości. Nie jest to też propozycja noweli, porzucenia dobrych, z dawna dzierżonych przez panującego uprawnień, lecz wskazanie starego, chwalebnego zwyczaju, który jako takowy, i to jeszcze obserwowany przez wzór cnót monarszych Bolesława Chrobrego, miałby zasadniczy walor.

Niejako w negatywie terytorialny charakter zarządu grodowego ukazuje się w zupełnie innym miejscu kroniki: w r. 24 ks. III, Gall informując o wyprawie Krzywoustego na Prusy, wyjaśnia, że nie doszło tam ani do bitwy, ani do żadnych oblężeń (jak na Pomorzu), Bolesław non castella, non civitates, quia ibi nulla, sibi obsedit, quippe situ loci et naturali positione regio ista per insulas lacubus et paludibus est munita, et per sortes hereditarias ruricolis et habitatoribus dispartita ${ }^{42}$. Zatem według Galla w kraju Prusów nie ma grodów, bo są niepotrzebne, kraj jest bezpieczny dzięki naturalnym przeszkodom. Jak zatem kraj ów jest podzielony? Na dziedziczne źrebia. Nie ma okręgów grodowych, a zatem też i władzy, która by agregowała pod sobą większe terytorium i na innej zasadzie niż tytuł dziedziczny. Jest to skądinąd raczej uproszczony, zideologizowany punkt widzenia. Nie sposób na podstawie tej wzmianki przyjąć, by Prusowie nie mieli w ogóle żadnych grodów, i by obywali się bez jakichkolwiek struktur władczych czy szczepowych poza nuklearnymi (i ich materialnymi demonstracjami).

Rozdział 15 ks. I, w którym Gall opowiada anegdotkę o tym, jak to Bolesław Chrobry wolał nie tracić z oczu pogranicza, i miast wyprawiać uroczyste świąteczne uczty, ani pozwalać na marnotrawstwo przygotowanych szat i posiłków, nakazał je

\footnotetext{
39 Patrz J. Banaszkiewicz, Otto III jedzie do Gniezna, s. 186-190.

40 Por. K. Buczek, Gospodarcze funkcje, s. 180-181, 185.

41 Por. K. Modzelewski, Organizacja gospodarcza, s. 29.

42 Anonim, ks. III, r. 24, s. 154.
} 
rozdawać ${ }^{43}$, zwraca już uwagę w kontekście organizacji owych świąt dorocznych. Mieli kierować nimi villici ac vicedomini Bolesława - przy czym owe uroczystości miały być przygotowywane in singulis civitatibus. Najwyraźniej jednak dotyczyłoby to tylko grodów stołecznych bądź wybranych z uwagi na doraźne miejsce pobytu Bolesława, trudno bowiem przypuszczać, aby panujący (o jego to udział w święcie chodziło) planował przebywać jednocześnie we wszystkich grodach. Sens tej opowieści był następujący: panujący urządzał ceremonialne (tj. przynależne do sfery komunikacji symbolicznej) uczty świąteczne w wybranych grodach (pewnie prominentnych), zamiast samemu w nich uczestniczyć, uważając, że wpuszczenie wroga w granice przez brak czujności (przy biesiadowaniu) przyczyniłoby się do utraty także i tego, co by rozdano oraz zjedzono podczas owych uczt. Anonim organizację tych uroczystości przedstawił następująco: panujący wybranych dworzan - singulos singulis civitatibus vel castellis deputabat qui loco sui castellis et civitatibus convivia celebrarent ac indumenta aliaque dona regalia quae rex dare consueverat, suis fidelibus presentarent ${ }^{44}$. Civitates et castella są tu w zasadzie tylko miejscami, w których owe uroczystości miałoby się urządzać, i gdzie nagradza się wiernych królowi. Czy można wynieść stąd jakieś wnioski co do tego, czy owe miasta i grody pełniły jakąś rolę rezydencjonalną oraz gospodarczą? Raczej nie. Najwyraźniej mamy tu do czynienia z poddanym logice narracji opisem uroczystości dworskich ${ }^{45}$, które wszakże miały odbywać się pod nieobecność władcy, choć na jego polecenie. Nie sposób przyjąć bez wątpliwości, iż byłby to obyczaj powszechny, i że mamy tu demonstrację działania jakiegoś aparatu gospodarczego oraz jego personelu ulokowanego w grodach. Ważniejsze jest w ujęciu Anonima przeciwstawienie i zarazem pogodzenie ceremonialnego charakteru sprawowania władzy, a także obowiązków militarnych władcy. Porzucenie świętowania oznaczałoby złamanie umowy społecznej - przynajmniej wobec elity, jak można się domyślać, stanowiłoby zapewne również rezygnację z rytuału okazywania królewskiej szczodrości i kontaktu z poddanymi. Zarazem świętowanie w sytuacji zagrożenia byłoby oznaką gnuśności, porzucenia przez monarchę jednego z najznaczniejszych obowiązków, tj. obrony władztwa i dbałości o jego całość.

Mamy zatem tu podkreśloną chwalebną szczodrość Bolesława, przeciwstawioną marnotrawstwu, a także jego dbałość o całość i bezpieczeństwo swych dziedzin i pod-

\footnotetext{
43 Anonim, ks. I, r. 15, s. 34-35.

44 Anonim, ks. I, r. 15, s. 35.

45 Por. m.in. J. Banaszkiewicz, Trzy razy uczta, [w: ] Społeczeństwo Polski Średniowiecznej, t. 5, red. S.K. Kuczyński, Warszawa 1992, s. 95-108; M. Dygo, Uczty Bolesława Chrobrego, Kwart. Hist. 112 (2005), nr 3, s. 41-54 (por. P. Wiszewski, Domus Boleslai, s. 211); F. Curta, Gift-giving, s. 124-125.
} 
danych ${ }^{46}$. Rytualny wymiar uczty świątecznej połączonej z rozdawaniem darów, celebrującej przybycie panującego i pokój wewnętrzny, jest tu zestawiony (w pozornej sprzeczności) z cnotami rycerskimi władcy, chroniącego ów pokój ${ }^{47}$. Literalne odczytanie tego fragmentu prowadziłoby do próby odtwarzania systemu ekonomicznego monarchii, z odgadywaniem organizacji świąt i ich charakteru, podziału obowiązków pomiędzy urzędników panującego etc. - tymczasem kluczem do odczytania tego fragmentu jest raczej obszar obowiązków (nie tylko symbolicznych) władcy ${ }^{48}$.

Rozpatrywanie, czy uroczystości takie jak wspomniane przez Anonima miały - przynajmniej jeśli idzie o posiłki i picie - być przygotowane w wyznaczonych grodach, a zatem z tamecznych komór czy piwnic (co, jak się zdaje, może nie być pozbawione znaczenia w świetle późniejszych źródel) oraz jaki segment organizacji monarchii był za nie odpowiedzialny, nie może przynieść zatem znaczących wniosków. Jakkolwiek zarysowuje tło opowieści, nie jest to raport z działania organizacji gospodarczej.

Co jest istotne w tym fragmencie kroniki, i co łączy go z rozdz. $12 \mathrm{ks}$. I, to przekonanie Anonima o powiązaniu - choćby w sferze symbolicznej czy postulowanej - zarządu monarchii z grodami: to jest własność panującego, tam ma mieć servitium determinatum, tam wydawać świąteczne uczty, tam są zapewne komory i skarbce, $\mathrm{z}$ których rozdawane są dary, to w ośrodkach grodowych rezydują nie tylko dowódcy wojskowi, ale i rozmaici rządcy z ramienia władcy. Zakres władzy związanej z grodami u Anonima jest terytorialny - i odnosi się raczej nie tyle do ludzi w konkretnych otaczających grody osadach, ale operuje pojęciem granicy - tzn. granicy między kompetencjami, zasięgiem władzy i służby rządców grodowych.

Przejście od Gallowego złotego wieku do ołowianego znaczy również przejście od historii zestawionej w katalog cnót panującego do wywodu również pouczającego, ale już przywiązującego uwagę do kolejności wydarzeń - zapewne lepiej już

46 Por. P. Żmudzki, Władca, s. 344-347, gdzie streszczona podobna laudacja Włodzimierza Monomacha w Powieści lat minionych.

47 Por. G. Althoff, Potęga rytuału. Symbolika władzy w średniowieczu, Warszawa 2011, s. 49-50; Z. Dalewski, Rytuat i polityka. Opowieść Galla Anonima o konflikcie Bolesława Krzywoustego ze Zbigniewem, Warszawa 2005, s. 15; tenże, Polityka, rytuat i tekst, [w:] Źródło. Teksty o kulturze średniowiecza ofiarowane Bronistawowi Geremkowi, red. W. Brojer, Warszawa 2003, s. 17-21; F. Curta, Gift-giving and violence in Bulgaria and Poland. A Comparative Approach to Ruling Strategies in the Early Middle Ages, [w: ] Consensus or Violence? Cohesive forces in Early and High Medieval societies $\left(9^{\text {th }}-14^{\text {th }}\right.$ c.), ed. S. Moździoch, P. Wiszewski, Wrocław 2013, s. 124 n.

48 Por. K. Modzelewski, Organizacja gospodarcza, s. 76; tenże, Chtopi, s. 130; K. Buczek, Gospodarcze funkcje, s. 180-181, 185. 
Gallowi, a raczej jego relatorom, znanych. Przejście to oznacza przygotowanie faktograficzne dla opowieści o Bolesławie Krzywoustym ${ }^{49}$.

Panowanie nad grodami, nominacje, ewentualnie „dawanie” grodu jest oznaką władzy nad nim, zarówno możliwej do delegowania, jak i alienacji. Panowanie nad grodem to również sprawowanie władzy nad terytorium - albo w najbardziej doraźny, militarny sposób, albo też, jeżeli wskażemy ewentualnie inne momenty tej władzy, także polityczne.

Znaczące jest to, jak Gall, opisuje zarówno utratę władzy, jak i odzyskanie jej przez Kazimierza Odnowiciela: gdy według kronikarza Kazimierza wygnano, reges et duces in circuitu Poloniam quisque de parte sua conculcabat, suoque dominio civitates quisque castella contigua vel applicabat vel vincendo terrae coequabat ${ }^{50}$. Kazimierz, powróciwszy do Polski, castrum quoddam a suis sibi redditum acquisivit ${ }^{51}$. Odzyskanie bezbronnej bez władcy ziemi, zaczyna się od opanowania grodu. Można powiedzieć, że jest to oznaka panowania nad terytorium i ostateczna podpora władzy monarchy - zwłaszcza w sytuacji skrajnej. Szerzej Gall opisuje krótkotrwały podbój Pomorza przez Władysława Hermana: książę, zwyciężywszy w bitwie, civitates eorum [Pomorzan] et municipia infra terram et circa maritima violenter occupavit, suosque vastaldiones et comites in locis principalioribus et munitioribus ordinavit ${ }^{52}$, by następnie dla zastraszenia ludności, nakazać spalenie grodów położonych in meditullio regni, w interiorze. Należy przypuszczać, że chodzi tu o te pośledniejsze grody, w których władca nie ustanowił urzędników, i które tym samym mogłyby stać się zawadą w rządach nad Pomorzem. Ustanowienie swego rządu nad grodem, jak pokazuje dalsza wzmianka Anonima dotycząca walk Bolesława ze Zbigniewem, odbywało się przez ustanowienie w nim swego komesa (tam: w Gnieźnie) $)^{53}$.

W rozdziale 20 ks. I, gdzie Anonim opowiada o odbiciu przez Kazimierza z rąk Miecława Mazowsza, czytamy jak ten pierwszy wynagrodził rycerza, który mu ocalił życie, pochodzącego non de nobilium genere, sed de gregariis militibus, w ten sposób, że później nam et civitatem ei contulit, et eum dignitate inter nobiliores extulit ${ }^{54}$. Zwykły rycerz dając przykład swej szlachetności, w nagrodę nie tylko otrzymuje gród,

\footnotetext{
49 E. Skibiński, Kronika Galla, s. 239-240.

50 Anonim, ks. I, r. 19, s. 42.

51 Anonim, ks. I, r. 19, s. 44.

52 Anonim, ks. II, r. 2, s. 65.

53 Anonim, ks. III, r. 38, s. 108.

54 Anonim, ks. I, r. 20, s. 46.
} 
ale i zostaje podniesiony w godności pomiędzy szlachetniejszych. Ten fragment, wyjątkowy w wymowie ze względu na stosowaną przez Anonima skalę pojęć społecznych ${ }^{55}$, odnosi się prawdopodobnie do przodka jednego ze współczesnych Galla, nie jest wykluczone, że był czytelny dla odbiorców. Być może kryje się tu jeszcze inny zabieg: Kazimierz podnosi w godności zasługującego na to przedstawiciela pośledniejszego rycerstwa, daje mu gród - a nieco dalej czytamy o Sieciechu, który mianuje swoje kreatury, wynosząc je niezasłużenie, gwoli swoim intrygom ${ }^{56}$. Istotne wydaje się jeszcze jedno: panujący ma swobodę w „dawaniu” grodów (cokolwiek miałoby to oznaczać - możliwe, że była to nominacja, jak i realne nadanie). Podobnie Anonim pisze o tym, jak Bolesław Krzywousty przed i w oktawie swego ślubu rozdawał zdobne futra, szaty, złote i srebrne naczynia, civitates et castella, a jeszcze innym wsie i posiadłości (villas et predia) ${ }^{57}$.

W relacji Galla o rządach Władysława Hermana wątek nominacji na urzędy związane z grodami jest obecny w tle, podkreślając pewne znaczące momenty konfliktu księcia i synów, dzięki czemu jesteśmy w stanie dowiedzieć się czegoś więcej o strukturze władztwa. Władysław Herman, opanowawszy Pomorze w początku swych rządów, suos vastaldiones et comites in locis principalioribus et munitioribus ordinavit $t^{58}$. Dalej jednak Gall dodaje, że w istocie ustanowił ich Sieciech (wonczas princeps militiae, wojewoda - to wtrącenie miało najwyraźniej objaśniać, że był to tytuł, dla którego Sieciech był władny owych nominacji w imieniu panującego dokonać) - co miałoby być jedną - obok buntu Pomorzan - z przyczyn utraty Pomorza, jako że obok szlachetniejszych, którym dano zbiec, mianował ludzi, których z ich własnej winy pozabijano ${ }^{59}$. Gall poprzedza tym późniejsze zarzuty wobec Sieciecha, że ten ignobiles vero nobilibus praeponebat ${ }^{60}$, co najwyraźniej dokonywało się m.in. w ten sposób, iż Sieciech in castellis etiam puerorum [Zbigniewa i Bolesława] partibus deputatis aut sui generis, aut inferioris, quibus dominaretur, comites et pristaldos praeponebat ${ }^{61}$. Jest

55 K. Modzelewski, Comites, principes, s. 408-409.

56 Anonim, ks. II, r. 4, s. 68; byłaby to zatem jedna z zamierzonych antytez między ks. I a ks. II kroniki, por. W. Wójtowicz, Konstruowanie Galla, s. 122 n.

57 Anonim, ks. II, r. 23, s. 90.

58 Anonim, ks. II, r. 1, s. 65.

59 Anonim, ks. II, r. 1, s. 65: Nam quos Setheus eis prefecerat, qui tunc milicie princeps errat, partim pro eorum noxa peremerunt, nobiliores vero discretius et honestius se habentes, vix amicorum assensu fugaverunt.

60 Anonim, ks. II, r. 4, s. 68.

61 Anonim, ks. II, r. 16, s. 79. 
to o tyle wiarygodny element relacji Galla, że najwyraźniej system nominacji musiał być znaczący nie tylko dla żywotnie zainteresowanej elity władzy, ale i dla samych panujących. Kwestia Sieciechowej manipulacji nominacjami wraca w istotnym momencie, tj. gdy po uwolnieniu Zbigniewa (1097 r.) Władysław Herman wyznacza książętom-juniorom ich dzielnice.

Anonim w rozdziale ósmym drugiej księgi kroniki relacjonuje naradę możnych z Władysławem Hermanem nad podziałem kompetencji władcy po wydzieleniu dzielnic książętom-juniorom ${ }^{62}$. O co mieli pytać możni? Który z juniorów ma mieć znaczniejsze miejsce przy przyjmowaniu i wysyłaniu poselstw oraz zbieraniu i prowadzeniu wojska - i dopiero dalej w niesprecyzowanych sprawach 'zarządu królestwa' (...in tanti regni dispensacione multimoda) ${ }^{63}$. Odpowiedź włożona w usta Władysława Hermana wzywała możnych do posłuszeństwa roztropniejszemu i zacniejszemu w obronie ziemi i zwalczaniu wrogów (discretiori ac probiori in terrae defensione et hostium impugnatione $)^{64}$. Widzimy zatem, jak współcześni widzieli oprócz cnót władcy - główne kompetencje panującego - i były to kompetencje 'zewnętrzne’ tj. dyplomatyczne i militarne. Jak jednak podział władzy miał przekładać się na jej narzędzia? Opis wyznaczenia działów książętom juniorom ujawnia - jak się zdaje - szczebel organizacji grodowej: sedes regni principales, naczelne stolice królestwa: Wrocław, Kraków i Sandomierz (przy czym wymienione tu są tylko te leżące w dziale Bolesława, bez Zbigniewowego Mazowsza) ${ }^{65}$. Władysław Herman uprzednio wydzielając działy książętom-juniorom zatrzymuje sobie owe sedes regni principales $^{66} . \mathrm{Nb}$. poza tymi naczelnymi stolicami królestwa, które miał otrzymać po śmierci ojca Bolesław, musiały być inne - leżące w dziale Zbigniewa, tj. „tym, co

62 Anonim, ks. II, r. 8, s. 74-75; Patrz G. Labuda, Władystaw i Zbigniew. U genezy podziatów dzielnicowych w Polsce w drugiej połowie XI wieku, [w: Społeczeństwo Polski Średniowiecznej, t. 6, red. S.K. Kuczyński, Warszawa 1994, s. 17 n.

63 Anonim, ks. II, r. 8, s. 74.

64 Anonim, ks. II, r. 8, s. 75.

65 Anonim, ks. II, r. 8, s. 75; por. J. Wyrozumski, Kraków jako sedes regni principalis, [w:] Sedes Regni Principales. Materialy z konferencji. Sandomierz 20-21 października 1997 r., red. B. Trelińska, Sandomierz 1999, s. 19 n.; por. także T. Wasilewski, Sedes regni principales i sedes regni państwa polskiego jako ośrodki wojskowe, administracyjne i gospodarcze w XI i XII wieku, [w:] Sedes Regni Principales. Materialy z konferencji, s. 57-66; T. Lalik, Organizacja grodowo-prowincjonalna, s. 381-416; T. Wasilewski, Poland's administrative structure in early Piast Times. Castra ruled by Comites as Centers of Provinces and Territorial Administration, Acta Poloniae Historica 44 (1981), s. 5-31. 
obecnie [Zbigniew post 1097] posiada" ${ }^{67}$ - ewidentnie więc także w Wielkopolsce i w przyszłości na Mazowszu. Można zatem przypuszczać, że do owych stolic należałoby również wliczyć Poznań, Gniezno, Płock. Już wcześniej, relacjonując przyjęcie Zbigniewa przez Magnusa, komesa wrocławskiego, Anonim składa podszepty eksulantów-stronników starszego syna Władysława Hermana w ten sposób: ... tibi Magne, cui nomen ducatus est plus dedecori quam honori, lacrimabiliter condolemus, cum laborem honoris, nec honorem habeas, cum pristaldis Zethei dominari non audeas, sed si iugum servitutis de cervice volueris exculere, festina puerum [Zbigniewa] ... in clipeum defensionis recipere ${ }^{68}$. W innym miejscu Gall pisze o Bolesławie, który mimo młodego wieku, już władał ducatus Wratislaviensis ${ }^{69}$. Magnus, komes wrocławski, miałby zatem nosić tytuł książęcy (a nic nie wskazuje na to, by należał do rodu Piastów), co w zestawieniu z późniejszymi wzmiankami Galla o tym, że Wrocław jest sedes regni principalis, a Bolesław włada ducatus Wratizlaviensis, wydaje się przesądzać o tym, iż był to tytuł związany z zakresem władzy i obszarem powierzonego władztwa. Tomasz Jurek wskazał wszakże, że precyzyjnie posługujący się nomenklaturą tytułów Anonim, nie nazywa nikogo nie-książęcej kondycji tytułem $d u x$ - poza Magnusem ${ }^{70}$. Argumentacja stronników Zbigniewa (skonstruowana przez Galla) podkreśla 'administracyjny' charakter funkcji, ubliżający jednak statusowi komesa: Magnus miałby mieć z niej więcej trudów niż godności, musząc być posłusznym pristaldom Sieciecha. Możliwe wszakże, że tytuł książęcy Magnusa nie był li tylko powiązany z dzierżoną przezeń godnością. Jeżeli istotnie (przyjmując domniemania T. Jurka) był on wysokiego rodu anglosaskim eksulantem, wonczas $d u x$ to jego tytul osobisty ${ }^{71}$; $w$ takim przypadku złożona przez Galla perswazja stronników Zbigniewa sprowadzałaby się do okrutnego szyderstwa. Ewidentnie rdzeń argumentacji odnosi się jednak do rozbieżności między godnością komesa wrocławskiego - zapewne sprawującego rządy nad pryncypialnym grodem, a najpewniej nad całą prowincją - a nierównym, a wręcz ubliżającym traktowaniem go przez wojewodę. Można przypuszczać, że kwestia pozycji komesa Magnusa w hierarchii monarchii, w połączeniu z informacją tegoż

\footnotetext{
67 Anonim, ks. II, r. 8, s. 75: ...Zbigneus cum hoc, quod habet, Mazouiam simul habeat...

68 Anonim, ks. II, r. 4, s. 69.

69 Anonim, ks. II, r. 13, s. 78.

70 T. Jurek, Kim byt komes wroctawski Magnus?, [w:] Venerabiles, nobiles et honesti. Studia z dziejów społeczeństwa Polski średniowiecznej. Prace ofiarowane Profesorowi Januszowi Bieniakowi w siedzemdziesiąta rocznicę urodzin i czterdziestopięciolecie pracy naukowej, red. A. Radzimiński, A. Supruniuk, J. Wroniszewski, Toruń 1997, s. 183-184.

71 T. Jurek, Kim byt, s. 181-192.
} 
Galla o ducatus Wratislaviensis i (niepełną) listą sedes regni principales daje podstawy, by przypuszczać, że te ostatnie były nie tylko grodami rezydencjonalnymi, ale również siedzibami ogniw znacznego szczebla zarządu terytorialnego. Szczebel ten najwyraźniej po 1138 r. uległ zatarciu - choć jeszcze dla Wincentego Kadłubka był na tyle czytelny, by - być może niejako w kontynuacji Gallowej aksjologii hierarchii - tytułować zarówno Magnusa, Żyrę, jak i Henryka Kietlicza.

Kontrowersja pomiędzy Bolesławem Krzywoustym a Sieciechem (a najpewniej i Władysławem Hermanem) miała w przekazie Galla rozpocząć się m.in. od tego, że Sieciech miał po 1197 r. w grodach w działach Zbigniewa i Bolesława ustanawiać komesów i pristaldos związanych ze sobą - którzy mieli być posłuszni książętom-juniorom, lecz w istocie nie byli ${ }^{72}$. Najwyraźniej chodzi tu o grody inne niż sedes regni principales, jeszcze przecież znajdujące się w ręku Władysława. Widać tu napięcie pomiędzy formalnymi uprawnieniami palatyna i książąt-juniorów, a tworzącymi realną strukturę władzy więziami nieformalnymi: Sieciech mianuje urzędników jak i uprzednio, najpewniej z ramienia panującego - kreuje swoich ludzi, by móc na nich wpływać mimo książąt-juniorów. Ewidentnie przedmiotem kontrowersji nie były uprawnienia palatyna do nominacji zwierzchników grodów - jak można przypuszczać, zachowane z czasów poprzedzających wydzielenie juniorom dzielnic - ale jego machinacje, faktycznie ograniczające władzę książąt-juniorów nad komesami i grodami. W polu widzenia kronikarza te okoliczności musiały znaleźć się nie bez powodu: konieczne było wskazanie przyczyn konfliktu, z zachowaniem wiarygodności przekazu - wiarygodności wobec współczesnych odbiorców. Wzmianka wskazuje, że książęta-juniorzy faktycznie sprawowali władzę z ramienia wielkiego księcia, który (poprzez swego wojewodę) zachował dość istotną prerogatywę, jaką było desygnowanie urzędników w grodach; czyżby zatem dzielnice książąt-juniorów były w zasadzie tylko namiestnictwami, i to o ograniczonych uprawnieniach? Koresponduje to nb. ze sformułowaną przez Janusza Bieniaka opinią odnośnie do natury rządów dzielnicowych w Polsce po 1138 r., jako nie-dziedzicznego namiestnictwa książąt juniorów z ramienia wielkiego księcia ${ }^{73}$ - byłby to zatem wyraz kontynuacji

\footnotetext{
72 Anonim, ks. II, r. 16, s. 79-80.

73 J. Bieniak, Powstanie księstwa opolsko-raciborskiego jako wyraz przeksztatcania się Polski w dzielnicowa poliarchię, [w:] Sacra Silentii Provincia. 800 lat dziedzicznego księstwa opolskiego (1202-2002), red. A. Pobóg-Lenartowicz, Opole 2003, s. 37-40, 52-55, 79-81; por. także St. Kwiatkowski, Pamięć elit, s. 137-138; T. Ginter, Działalność fundacyjna księcia Mieszka III Starego, Kraków 2008, s. 17-19; K. Fokt, Książęta i namiestnicy. Historycznoustrojowa glossa do Janusza Bieniaka wizji ustroju drugiej monarchii piastowskiej, Krakowskie Studia z Historii Państwa i Prawa 9 (2016), z. 4, s. 471-486.
} 
takowych praktyk. Znacząca wobec powyżej omawianego zakresu władzy palatyna jest informacja Galla, że po ostatecznym zegnaniu Sieciecha Władysław Herman nullum tamen in curia sua palatinum vel palatini vicarium praefecit, omnia namque per se ipsum vel suo consilio sagaciter ordinabat, vel cuilibet comiti, cuius provinciam visitabat, curie responsionem et sollicitudinem commendabat ${ }^{74}$. Chodzi tu wprost o komesów prowincjonalnych, a nie grodowych (choć widać tu pewną zbieżność z powiastką $\mathrm{z}$ rozdziału $12 \mathrm{ks}$. I o podróżach i servitium determinatum Bolesława Chrobrego). Warto zaznaczyć, że Władysław Herman czynił tak pristine seditione reminiscens wystawia trochę inne świadectwo temu księciu niż powolnego demonicznemu Sieciechowi. Poza tą wzmianką (jak widać, mówiącą o nadzwyczajnych obowiązkach komesów nie tyle grodowych, ile prowincjonalnych), jak i historią buntu Magnusa (także najwyraźniej dotyczącą komesa prowincjonalnego), nie spotykamy w zasadzie poważniejszych wzmianek o charakterze i zasięgu władzy komesów - jeżeli nie wziąć pod uwagę uwagi o zgromadzonych gdzieś na granicy z Czechami marchiones, którzy rozbili wyprawę stronników Zbigniewa ${ }^{75}$. Jeżeli mieli to być komesi granicznych grodów, przezwani margrabiami czy to przez Galla, czy to w rzeczywistości noszący taki tytuł, przypuszczalnie ich specjalnym obowiązkiem była obrona granicy.

W ujęciu Galla widzimy zatem organizację grodową Polski jako strukturę hierarchiczną ${ }^{76}, w$ imieniu panującego zarządzaną przez komesa pałacowego, wojewodę, o najwyraźniej dwustopniowym podziale: prowincjonalnym i lokalnym, ze zbieżnością między obecnością komesów prowincjonalnych a wyróżnieniem sedes regni principales, grodów o istotnym znaczeniu - najpewniej stolic owych prowincji (mimo braku pewności co do tego, czy termin Anonima był raczej swobodnym określeniem znaczności tych grodów, czy oddawał ich formalną rangę ${ }^{77}$ ). Terminologia hierarchii u Galla, jakkolwiek stosowana przezeń precyzyjnie, nie odpowiada późniejszej praktyce kancelaryjnej (pristaldi i vastaldiones zniknęli), co by wskazywało, że pewne terminy łacińskie ukuł on sam, i nie miały one kontynuacji. Same funkcje

\footnotetext{
74 Anonim, ks. II, r. 21, s. 88.

75 Anonim, ks. III, r. 19, s. 144-145.

76 W sprawie struktur urzędniczych wczesnej monarchii piastowskiej patrz J. Kurtyka, Hofämter, Landesämter, Staatsämter und ihre Hierarchien in Polen im mitteleuropäischen Vergleich (11.-15. Jh.), [w: ] Das Reich und Polen. Parallelen, Interaktionen und Formen der Akkulturation im hohen und späten Mittelalter, hrgb. v. T. Wünsch, Ostfildern 2003, s. 129-213.

77 Por. J. Wyrozumski, Kraków jako sedes regni principalis, s. 19-25; por. także T. Wasilewski, Sedes regni principales, s. 57-66; T. Lalik, Organizacja grodowo-prowincjonalna, s. 381-416; T. Wasilewski, Poland's administrative structure, s. 5-31; Z. Dalewski, Wtadza, przestrzeń, ceremoniat, s. 58-70.
} 
nie musiały zniknąć, widoczna jest jednak dyskontynuacja nomenklatury (co by wskazywało nie tyle na to, że doszło do zmian w strukturze zarządu monarchii, ale raczej, że kronika nie miała wpływu na późniejszą terminologię kancelaryjną). Co istotne, nomenklatura, jaką Anonim posługuje się w całej kronice, by odnosić się do urzędników zarządu monarchii (tytuły vastandiones, villici, vicedomini, comites) jest przezeń stosowana precyzyjnie i z zachowaniem hierarchii, co wskazywałoby, że dotyczyła realnych stanowisk i ich hierarchii ${ }^{78}$. Stary tytul comes, powiązany w kronice zarówno $\mathrm{z}$ władztwem grodowym i prowincjonalnym (tak w przypadku Magnusa, jak i zapewne komesa powołanego przez Zbigniewa w Gnieźnie) i wojewodzińskim, najwyraźniej był już wtedy ustabilizowany, nie należał do sfery tytulatury przez Anonima stworzonej - i, jak się zdaje, dopiero czekała go pewna ewolucja, mająca zróżnicować nomenklaturę władzy ${ }^{79}$.

\section{Kronika Mistrza Wincentego zw. Kadłubkiem}

Wzmianki o grodach jako ogniwach struktur władczych rozmieszczone w kronice Mistrza Wincentego demonstrują niekiedy zbieżności z ujęciem Anonima, co wszakże nie musi być tylko wynikiem przejęcia schematu Anonima, ale po prostu wynikać z oczywistości opisywanych okoliczności ${ }^{80}$. Informacje dotyczące struktur

78 K. Modzelewski, Organizacja gospodarcza, s. 108-110; K. Modzelewski, Comites, principes, nobiles. Struktura klasy panującej w świetle terminologii Anonima Galla, [w:] Cultus et cognitio. Studia z dziejów średniowiecznej kultury, red. S.K. Kuczyński, Warszawa 1976, s. 403-412; por. także T. Jurek, Kim byt, s. 183; W. Sawicki, Terminologia prawnicza Anonima Galla w świetle instytucji obcych i rodzimych, Annales UMCS, sectio G - Ius 17 (1970), s. 2-3.

79 Por. K. Modzelewski, Comites, principes, s. 405-406; por. A. Bogucki, O żupanach w Polsce piastowskiej, [w:] Społeczeństwo Polski Średniowiecznej, t. 4, red. S. K. Kuczyński, Warszawa 1990, s. 115-146; A. Bogucki, Komes w polskich źródłach średniowiecznych, Warszawa - Poznań 1972, s. 26 n., 101 n.; A. Gąsiorowski, Castellanus. Przyczynek semazjologiczny, Slavia Antiqua 18 (1971); A. Gieysztor, Kasztelanowie flandryjscy i polscy. Zagadnienie porównawcze, [w:] Studia historyczne. Księga jubileuszowa S. Arnolda, Warszawa 1965, s. 97-107; J. Kurtyka, Hofämter, s. 151-152; T. Lalik, Organizacja grodowo-prowincjonalna, s. 383-385.

80 Ws. kroniki Kadłubka patrz materiały sympozjum Rok nauki polskiej 1973. Mistrz Wincenty Kadtubek - pierwszy uczony polski - w 750-lecie śmierci, opublikowane w nr 20 z 1976 r. Studiów Źródłoznawczych-Commentationes, a także nowsze badania, m.in.: J. Banaszkiewicz, Polskie dzieje bajeczne, Wrocław 2002 (wyd. 2); Onus Athlanteum. Studia nad Kronika biskupa Wincentego, red. A. Dąbrówka, W. Wojtowicz, Warszawa 2009; materiały sesji Btogosławiony Wincenty Kadtubek. W 800-lecie sakry biskupiej, opublikowane pod red. M. Starzyńskiego i M. Zdanka w r. 2, zesz. 2 z 2008 r. (wł. 2009) Cistertium Mater Nostra. Tradycja-Historia-Kultura; Z. Kałuża, Lektury filozoficz- 
monarchii u Mistrza Wincentego rozłożone są wszelako w siatce pojęć, którymi kronikarz się posługiwał, a tym samym w planie ideowym kroniki ${ }^{81}$.

Znaczący jest fragment kroniki mistrza Wincentego, który traktuje o tzw. rzezi wiślickiej $^{82}$ : węgierskiego zbiega przyjmuje Bolesław Krzywousty, który tegoż gloriosa Visliczensium urbe urbis prefectum constituit. Zbieg przyzwał Władymirka Wołodarowica, by następnie pod pozorem obrony zarządzić lokalną mobilizację, a później wydać gród ruskiemu księciu. Kadłubek wydanie rozkazu schronienia się do grodu w obliczu wroga spisał w słowach: hostes itaque pre foribus inminere preconatur, principali edicto imperat, qui extra oppidum delituerit, reum esse maiestatis, omni supellectile fisco accessura ${ }^{83}$. Wydawcy zaznaczyli zapożyczenie towarzyszących temu fragmentowi fraz z Digestów, jak i rzymską stylistykę samego rozkazu ${ }^{84}$. Czy można ufać temu opisowi jako odpowiadającemu stosunkom władczym za czasów Bolesława Krzy-

ne Wincentego Kadtubka. Zbiór studiów, Warszawa 2014; Writing history in Medieval Poland. Bishop Vincentius of Cracow and the 'Chronica Polonorum', ed. D. von Güttner-Sporzyński [Brepols], 2017; G. Vercamer, Historiographische Strategien, die herrschaftlichen Strukturen in Polen und im Reich im 12. Jahrhundert zu stabilisieren - Ottos/Rahewins Gesta Friderici und Vincentius' Chronica Polonorum im Vergleich über den, guter Herrscher', [w:] Consensus or Violence? Cohesive forces in Early and High Medieval societies $\left(9^{\text {th }}-14^{\text {th }}\right.$ c.), ed. S.. Moździoch, P. Wiszewski, Wroclaw 2013, s. 145-180.

81 Patrz m.in.: A. Bogucki, Terminologia polityczna w Kronice mistrza Wincentego, Studia Źródłoznawcze-Commentationes 20 (1976), s. 56-63; P. Żmudzki, Vincentius's Construct of a Nation: Poland as res publica, [w:] Writing history, s. 175-197; E. Mühle, Adaptacja antycznego pojęcia „res publica" w Kronice polskiej mistrza Wincentego, [w:] Ecclesia. Regnum. Fontes. Studia z dziejów Średniowiecza. Prace ofiarowane Profesor Marii Koczerskiej, red. S. Gawlas, K. Gołąbek, R. Michałowski, M. Piber-Zbieranowska, P. Węcowski, Warszawa 2015, s. 334-345; E. Skibiński, The Narrative in Vincentius's Chronicle, [w:] Writing history, s. 99-117; M.R. Pauk, Lords and Peasants: Polish Society and Economy in Transition, [w:] Writing history, s. 243-266; P. Wiszewski, Między obrazem a rzeczywistościa. Wtadza ksiażęca w kronice mistrza Wincentego, [w:] Potestas et societas. Wtadza w średniowiecznej Europie, red. P. Wiszewski, J. Wojtkowiak, Wrocław 2014, s. 83-109; J. Bieniak, Jak Wincenty rozumial i przedstawiat ustrój państwa polskiego, [w:] Onus Athlanteum, s. 43-46; E. Skibiński, Walka o wtadze w kronice Mistrza Wincentego. Mieszko Stary i Kazimierz Sprawiedliwy, [w:] Onus Athlanteum, s. 49-56. 82 Mistrza Wincentego zwanego Kadtubkiem Kronika Polska, wyd. M. Plezia, MPH SN t. 11 (dalej Kadtubek), ks. III, r. 22, s. 110-112.

83 Kadlubek, ks. III, 22.4, s. 111.

84 Kadlubek, index auctorum, s. 204: Digesta XXXIX.1.5.12; Mistrz Wincenty (tzw. Kadlubek): Kronika Polska, przeł. i opr. B. Kürbis, Wroclaw - Warszawa - Kraków 1996, wyd. 2, seria I Biblioteki Narodowej, nr 277, s. 149, przyp. 131; ws. recepcji prawa rzymskiego w kronice Mistrza Wincentego patrz m.in. A. Vetulani, Prawo kanoniczne i rzymskie w Kronice mistrza Wincentego, Studia Źródłoznawcze-Commentationes 20 (1976), s. 35-45; J. Sondel, W sprawie prawa rzymskiego w „Kronice Polskiej” Wincentego Kadlubka, Kwart. Hist. 85 (1978), nr 1, s. 95-105. 
woustego, a może raczej Kazimierza Sprawiedliwego? Rzymski sztafaż, spiżowa fraza mogły odpowiadać temu, w jaki Wincenty chciał przedstawić władztwo grodowe.

Podtrzymanie własnej władzy poprzez zajęcie grodów, wygląda niemal identycznie jak w kronice Galla: mistrz Wincenty np. opisuje, kiedy to po konfrontacji $\mathrm{z}$ książętami-juniorami w bitwie pod Poznaniem, Władysław [Wygnaniec] munitissime tamen presidiatis urbibus, imperatoram adit serenitatem ${ }^{85}$. Podobnie jak było to w przypadku „statutu Władysława Hermana”, Wincenty informuje, że po przywróceniu synów Władysława Wygnańca do władztwa na Śląsku, Bolesław Kędzierzawy: Quia vero quasdam illius provincie urbes ad habundantiorem cautelam donationi exceperat $[. . .]^{86}$. Władysławowicy zażądali według Kadłubka (znów posługującego się tu rzymskimi klauzulami prawnymi ${ }^{87}$ ) korzystniejszego określenia statusu swego władztwa na Śląsku - co mogło się w kolejnym rzędzie odnosić (i najpewniej się odnosiło) także do wydania grodów zajętych przez Bolesława Kędzierzawego. Przy sposobności książęta zajęli grody i dodatkowo je umocnili i obsadzili (jak należy się domyślać, by chronić je przed zajęciem): ... occupant illi municipia, arte muniunt, roborant presidiis ${ }^{88}$. Był więc to akt polityczny, nie tylko militarny.

Władza nad grodem była (podobnie jak i u Anonima) znaczącym oparciem, nieraz ostatnim, jak w przypadku Mieszka Starego, któremu po utracie władzy w Wielkopolsce ostało się tylko finitimum ... oppidulum ${ }^{89}$. Niemal w tym samym momencie przed Kazimierzem omnium urbes prouinciarum ac municipia sine bello gratulanter patefiunt (z wyjątkiem Śląska opanowywanego przez Mieszka Władysławowica ${ }^{90}$. Osadzanie, względnie wspieranie we władzy w ujęciu Wincentego, również Kazimierz dokonywał przez przekazywanie grodów: kilku Mieszkowi Władysławowicowi, „marchii głogowskiej” Konradowi Plątonogiemu, „marchii gdańskiej” Samborowi ${ }^{91}$, czy też ich przyłączanie (jak 'prowincji' przemyskiej cum oppidis contingentibus ${ }^{92}$ ). Powrót Mieszka Starego do władzy w Wielkopolsce w 1181 r. również polega na zdobywaniu i zajmowaniu grodów: najpierw Gniezna, później omnes pa-

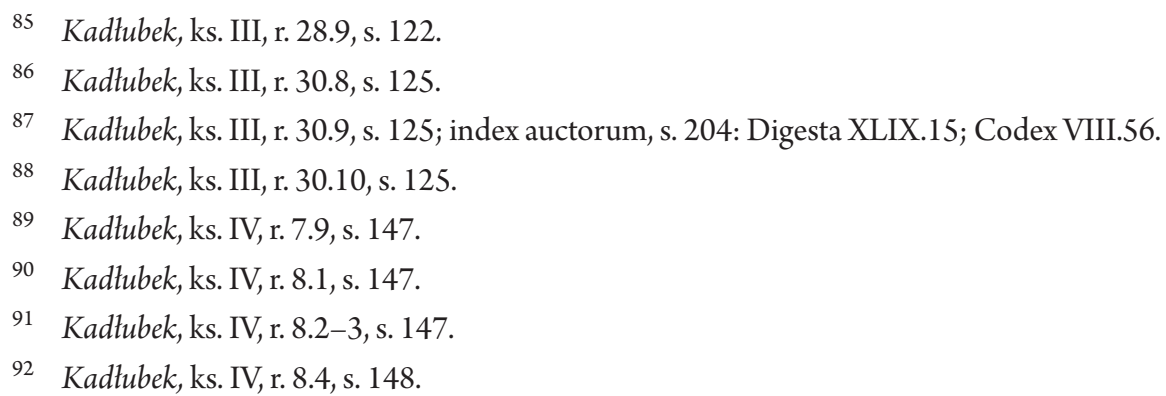


trimoniales ... munitiones ... recuperat ${ }^{93}$. Wraz z buntem stronników Henryka Kietlicza przeciw Kazimierzowi Sprawiedliwemu traditur civitas, produntur municipia ${ }^{94}$, już po śmierci Kazimierza i bitwie pod Mozgawą Mieszko uzyskawszy ponownie pryncypat, zajmuje m.in. Wiślicę i nie wymienione z nazwy trzy grody ${ }^{95}$ - tu jednak powołując się na ich przynależność do prowincji krakowskiej (co wskazywałoby, że składanie grodów w prowincje było przynajmniej zwyczajowo, jeśli nie formalnie - np. być może przez uszeregowanie dostojników grodowych w hierarchiach prowincjonalnych - uregulowane). Osadzenie grodów małopolskich przez urbium praefectos mianowanych przez Mieszka jest wystarczające dla stwierdzenia objęcia przezeń realnej władzy w ziemi ${ }^{96}$. Odzyskanie Wawelu i pozostałych grodów przez Kazimierza, oznacza również powrót prawowitej władzy ${ }^{97}$.

Stanowisko Henryka Kietlicza, nie wymienionego przez Wincentego z imienia,

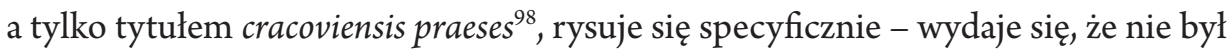
on rządcą samego tylko grodu krakowskiego, ale urzędnikiem dużo wyższej rangi. $\mathrm{Za}$ uzasadnione można uznać przypuszczenie J. Bieniaka, że jest on tożsamy z uprzednio wymienionym $\mathrm{w}$ kronice również anonimowo krakowskim namiestnikiem Mieszka Starego (dzierżącym jurysdykcję w zakresie regaliów), określonego tytułem praeses provinciae ${ }^{99}$ (podobnie Wincenty tytułuje Magnusa ${ }^{100}$ i Żyrę ${ }^{101}$ ). Również lista urzędów zagarniętych przez buntowników wypełniona jest republikańskimi tytułami rzymskimi (fasces, prefecturas, tribunatus, consulare decus ac senatorias potestates omnesque magistratuum potestates) i w zasadzie niemożliwa do dopasowania do jakiejkolwiek hierarchii współczesnej ${ }^{102}$.

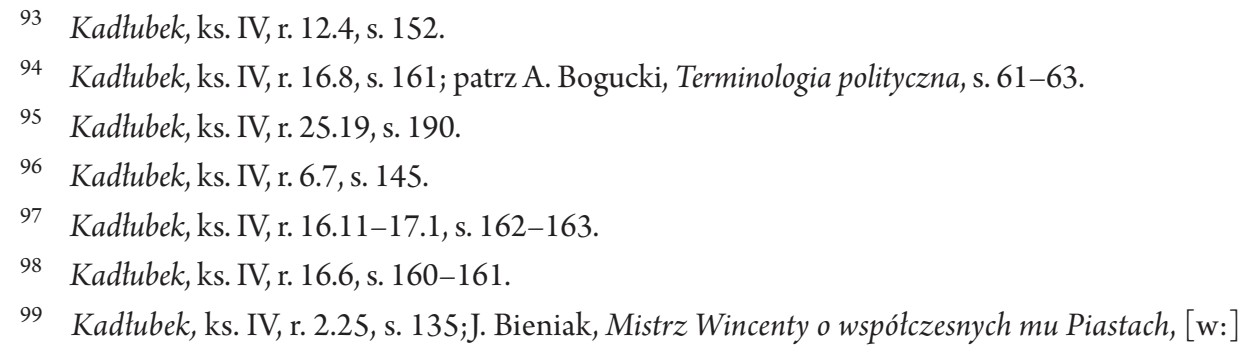
Europa środkowa i wschodnia w polityce Piastów, red. K. Zielińska-Melkowa, Toruń 1997, s. 35-37.

100 Kadtubek, ks. II, r. 22.16, s. 64: Et prius Silenciane preses provincie, cui nomen Magno...

101 Kadtubek, ks. II, r. 8.2, s. 147: ... [Kazimierz Sprawiedliwy] Lestconi [Bolesławowicowi] autem prouincias [tj. Mazowsze] paterno relictas testamento confirmat. Presidi earundem ... principi Syroni eius curam committit...

102 Kadtubek, ks. IV, r. 16.8, s. 161; patrz A. Bogucki, Terminologia polityczna, s. 61-63. 
Władza nad grodami dla Wincentego to władza nad terytorium, władza nad grodem stołecznym jest w jego perspektywie kluczowa. Jaki jednak jest kształt tej władzy? Wincenty wkłada w usta biskupa Pełki w kluczowym momencie, tj. po śmierci Kazimierza Sprawiedliwego, w trakcie dyskusji nad elekcją księcia, słowa: ... nam si res publica iuris testimonio instar habetur pupilli ... aut etami reipublice tutores non negabis. Nec enim per se principes rem publicam administrant, set per administratorias potestates $^{103}$. To zdanie Wincentego tworzy jeden ze znaczniejszych akcentów (obok opisu objęcia władztwa przez Kraka-Grakcha ${ }^{104}$ oraz powołania rządów przez Siemowita ${ }^{105}$ ) planu ideowego jego kroniki. Wskazuje również na to, iż w jego ujęciu i elita polityczna, i system zarządu władztwa czasu przejściowego między drugą monarchią piastowską a epoką suwerennych monarchii („poliarchią” za J. Bieniakiem), zasługiwały na polor antycznej nomenklatury. Rzymska terminologia i tytuły zastosowane przez Wincentego w jego ujęciu, oddaje strukturom władczym monarchii piastowskiej brakujący jej dotąd wyraz umocowania w siatce pojęć uznanego prawa (nieraz przesadnie - stąd zapewne tyle u Wincentego tytułów według Ambrożego Boguckiego „pustych”, tj. nie mających realnych odpowiedników $\left.{ }^{106}\right)$, staje się tu wehikułem przekonania o istocie władztwa jako bytu prawnego ${ }^{107}$.

\section{Władza jako system relacji}

Łatwo poczynić założenie idące w zasadzie za wishful thinking: grody były ośrodkami władzy, zatem też siedzibami instytucji, osób wyposażonych w konkretną władzę. Konsekwencje takiego założenia są bardzo daleko idące. Widzimy zatem grody jako siedziby władzy nie tylko militarnej, ale i wyposażonej w jurysdykcję, uprawnienia fiskalne i do odbioru rozmaitych świadczeń.

Tymczasem należałoby raczej zadać szereg pytań, które mogą pozostać bez odpowiedzi: grody były ośrodkami władzy, ale jakiej? Kto i w jakim stopniu ją sprawował? Jakie były jej źródła, cechy? Czy rozumiemy władzę jako mechanizm, zestaw metod, organizację, czy też jako sposób komunikacji? Kto władzę narzuca, kto ją uznaje,

\footnotetext{
103 Kadtubek, ks. IV, r. 21.13, s. 177.

104 Kadtubek, ks. I, r. 5.1-5.3, s. 9; por. J. Banaszkiewicz, Polskie dzieje bajeczne, s. 14, 22-23, 35.

105 Kadtubek, ks. II, r. 3.7, s. 32.

106 A. Bogucki, Terminologia polityczna, s. 62-63.

107 Nt. braku w praktyce kancelaryjnej rozwiniętych formuł oznaczających prawny abstrakt władzy por. K. Modzelewski, Organizacja gospodarcza, s. 86-87.
} 
jakie są mechanizmy jej akceptacji, jakie są jej narzędzia (rytuały), wreszcie jakie są zasady jej sprawowania: zwyczaj? dyskurs, względnie negocjacje? Konkretnych odpowiedzi na wiele tych pytań dać nie możemy z trywialnego powodu, tj. braku odpowiednich źródeł.

W odniesieniu od struktur władczych i społecznych niejednokrotnie stosuje się określenie „organizacja”. Może to sugerować plan, strukturę konstruowaną według pewnych założeń i schematu. Dotyczy to tak organizacji terytorialnej, hierarchii struktur władzy, jak i fenomenów monarchii wczesnopiastowskiej, tj. ludności służebnej i organizacji gospodarczej. Jest to, jak się zdaje, pewien anachronizm. Sugeruje to zastosowanie nowożytnych czy nawet nowoczesnych mechanizmów (i jak zauważył Karol Buczek: nie zawsze skutecznych ${ }^{108}$ - nb. przypuszczał on, że powstanie organizacji służebnej i „drużynniczej” armii Mieszka I złączone jest ścisłym związkiem funkcjonalnym, a nie „planem ekonomicznym”, jak w jego oczach miał zsyntetyzować ustrój monarchii wczesnopiastowskiej K. Modzelewski ${ }^{109}$ ) czy wręcz planu, do czasów odległych. Władztwo owego czasu raczej należy rozpatrywać jako system relacji, więzi, które generowały zasady i formy instytucjonalne. Odnosi się to również do metod jej sprawowania i kształtu jej uprawnień. Jest to między innymi powodem, dla którego jestem sceptycznie nastawiony do stosowania w odniesieniu do epoki post-antycznej i przed-nowożytnej terminu 'państwo', a tym bardziej 'państwowość' - zwłaszcza to ostatnie pojęcie, jako pewien abstrakt abstraktu, jest wyłącznie terminem gabinetowym ${ }^{110}$. Tymczasem za ówczesnymi stosunkami musiał stać pewien konkret, nie odwołujący się do zasad dostępnych dla wąskiej grupy, ale zrozumiały dla wszystkich stron ówczesnego systemu społecznego.

Wymowa wielu źródeł skłania do założenia, że w istocie u zarania władztwa Piastów był podbój. Podbój i przymus były narzędziami zdobycia terytoriów i poddania społeczności je zamieszkujących władzy, a także narzędziem utworzenia bądź modyfikacji systemu relacji, który ludzi tych miał utrzymać w zależności i współpracy $\mathrm{z}$ władztwem Piastów ${ }^{111}$. W zasadzie podbój więc byłby tylko i aż narzędziem ini-

108 K. Buczek, Organizacja stużebna, s. 141; por. uwagi P. Urbańczyka, Najdawniejsze stolice państwa piastowskiego, [w: ] Polska na przetomie I i II tysiąclecia. Materiały Sesji Stowarzyszenia Historyków Sztuki, Poznań, listopad 2000, red. Sz. Skibiński, Poznań 2001, s. 235-244.

109 K. Buczek, Organizacja stużebna, s. 140-141, 145-147.

110 Por. np. kryterium „państwowości” wg K. Buczka, odpowiadające stopniowi instytucjonalizacji władztwa, tenże, Targi, s. 28 .

111 Patrz ostatnio wydane prace zbiorowe: Tradycje i nowoczesność. Początki państwa polskiego na tle środkowoeuropejskim w badaniach interdyscyplinarnych, red. H. Kóčka-Krenz, M. Matla, M. Danielewski, 
cjującym zmianę relacji (lub ich nawiązanie) podległości, obowiązków i hierarchii, które możemy nazwać utworzeniem władztwa. Podbój i przymus narzuciły militarne narzędzia i sztafaż sprawowania władzy (nb. jak się zdaje, dobrze zrozumiały współczesnym). Wydaje się oczywiste, że władztwo powstałe poprzez dość szybki podbój oparło się w sferze materialnej o grody właśnie - by zapewnić sobie punkty oparcia nie tylko wobec ewentualnego niebezpieczeństwa zewnętrznego, ale i oporu czy przeciwdziałania na miejscu.

Rozmieszczenie grodów podążało za stosunkami osadniczymi i terytorialnymi momentami militarnymi - zatem można mówić o 'organizacji grodowej' nie w odniesieniu do terytorialnej sieci grodów, ale działania instytucji w tych grodach usadowionej. W pewnym sensie można mówić o budowie lokalnych instytucji władzy ad hoc, dla utrzymania i wykonywania jej - w tym sensie nie była ona 'organizacją', lecz stawała się nią dopiero poprzez połączenie działań tych instytucji i ujednolicenie ich wzorca. Łączyła je osoba panującego, jego otoczenia, tj. elity władzy, jak i generalnie rzecz ujmując - potrzeby militarne oraz materialne (fiskalne) monarchii wykraczające poza

Poznań 2016; Instytucja „wczesnego państwa” w perspektywie wielości i różnorodności kultur, red. J. Banaszkiewicz, M. Kara, H. Mamzer, Poznań 2013; Consensus or violence? Cohesive forces in Early and High Medieval societies $\left(9^{\text {th }}-14^{\text {th }}\right.$ c.), ed. S. Moździoch, P. Wiszewski, Wrocław 2013; Potestas et communitas. Interdisziplinäre Beiträge zu Wesen und Darstellung von Herrschaftverhältnissen im Mittelalter östlich der Elbe, hrgb. v. A. Paroń, S. Rossignol, B.Sz. Szmoniewski, G. Vercamer, Wrocław - Warszawa 2010, gdzie zarysowane perspektywy porównawcze dla Polski tego okresu i niektóre rozpoznane elementy procesów budowy wczesnych władztw, zwł.: F. Curta, Gift-giving and violence in Bulgaria and Poland. A Comparative Approach to Ruling Strategies in the Early Middle Ages, [w: ] Consensus, s. 113-134; S. Moździoch, Consensus or violence? Archaeology and the Beginnings of the Piast State, [w: Consensus, s. 299-310; P. Wiszewski, Different visions for different publicity? The early Piasts' communication strategy (c. 962-1058), [w: ] Consensus, s. 315-331;A. Paroń, S. Rossignol, B.Sz. Szmoniewski, G. Vercamer, Potestas et commuitas - Herrschaft und Sozialstrukturen. Einführende Gedanken, [w: ] Potestas, s. 13-19; S. Rossignol, D. Wehner, Methodologische Überlegungen zur interdisziplinären Erforschung von Herrschaft am Beispiel Ostmitteleuropas vom 9. zum 13. Jahrhundert, [w: ] Potestas, s. 23-52; patrz również K. Modzelewski, Chtopi, s. 251-258, 271 n, 276 n, 128-130, 156-159, 191-192; M. Kara, Archeologia o początkach państwa Piastów. Nowe aspekty i wyniki badań, [w: ] Tradycje i nowoczesność, s. 177-185; H. Mamzer, Pytania o istotę i zasady funkcjonowania "wczesnego państwa", [w: Instytucja "wczesnego państwa", s. 15-34; A. Ciesielska, Od "plemienia do państwa" czy "od wodzostwa do państwa"? Modele procesów państwotwórczych i nowe tendencje w ich badaniu, [w: Instytucja "wczesnego państwa", s. 53-71; M. Kara, Historiografia i archeologia polska o mechanizmach formowania się wtadzy Piastów. Próba zestawienia ważniejszych poglądów, [w: Instytucja "wczesnego państwa", s. 303-312; patrz także M. Kara, Najstarsze państwo Piastów - rezultat przełomu czy kontynuacji?, Poznań 2009; w sprawie trwałości przymusu jako narzędzia sprawowania rządów w społeczności przednowożytnej patrz K. Buczek, Egzekwowanie świadczeń publicznych w Polsce wczesnofeudalnej, [w:] Studia $z$ dziejów ustroju społeczno-gospodarczego Polski piastowskiej, wyd. W. Bukowski, t. 3, Kraków - Warszawa 2010, s. 234-236 [pierwodruk: Studia Historyczne 25 (1982), z. 3/4]. 
lokalne stosunki. Nie był to „plan”, lecz raczej zarząd, na rzecz którego ustalano pewne świadczenia, i prawdopodobnie postępująco ujednolicano je, czy powielano - a narzędziem ku temu było najwyraźniej wiązanie systemu tych świadczeń ze statusem ludzi do nich zobowiązanych, definiowanym jako relacja poddanych i panującego.

Jak zauważył K. Modzelewski, egzekwowanie świadczeń i pobór danin odbywały się na poziomie lokalnym, co powodowało, iż wczesne akty uposażeń instytutów kościelnych operowały informacjami o należnościach z podstawowych jednostek danniczych, którymi były okręgi grodowe ${ }^{112}$. Rodzi to zasadnicze pytanie o to, jak utrwalano i przenoszono wzorce egzekucji świadczeń, poboru danin - w skali władztwa liczącego znaczną liczbę takowych podstawowych jednostek. Nadrzędny, unifikujący wpływ na kształt tych wzorców (a tym samym poważnej części ustroju monarchii) miała najwyraźniej władza monarsza, narzucająca jednolity model podstawowych przynajmniej świadczeń i danin oraz będąca dla wspólnoty jej poddanych jedynym uzasadnieniem nakładanych na nich obowiązków. Nie wyklucza to lokalnych odrębności - wszakże umocowanych skinieniem panującego.

Można wskazywać mechanizm typowo organizacyjny, pozwalający na przenoszenie i utrwalanie pewnych wzorców świadczeń oraz obowiązków wobec monarchii, a także metod wykonywania przez jej aparat władzy (przede wszystkim jurysdykcji), tj. rotację lokalnej elity władzy, zapewne w połączeniu z pewnymi ścieżkami awansu, - niestety, jest on z oczywistych powodów dla X-XI w. praktycznie nieczytelny. $\mathrm{Z}$ drugiej strony, władza, by móc być wykonywaną, musi również zostać uznana, co m.in. oznacza, że za narzędziami sprawowania władzy (fiskalnymi i jurysdykcyjnymi) stała nie tylko praktyka władcza, ale i wpisanie ich w status osobisty-grupowy rządzonych. Kieruje to uwagę badacza na związanie ustroju monarchii wczesnopiastowskiej z prawami grupowymi - tak ludności wieśniaczej (przede wszystkim prawa chłopów-dziedziców), jak i prawa rycerskiego ${ }^{113}$.

Przymus i okupacja nie mogły jednak zapewnić trwałości władztwu w dłuższym okresie (a z pewnością rządzenie przy ich pomocy, choć zapewne skuteczne, byłoby niezwykle kosztowne) - tymczasem o kształcie organizacji terytorialnej monarchii

\footnotetext{
112 K. Modzelewski, Organizacja gospodarcza, s. 108 n.

113 K. Buczek, Organizacja stużebna, s. 145-146; tenże, Prawo rycerskie i powstanie stanu szlacheckiego $w$ Polsce, [w:] Studia z dziejów ustroju społeczno-gospodarczego Polski piastowskiej, wyd. W. Bukowski, t. 3, Kraków - Warszawa 2010, s. 160-161, 166-167, 172 [pierwodruk: Przegl. Hist. 69 (1978), z. 1]; tenże, O chtopach w Polsce piastowskiej (część druga), [w:] Studia z dziejów ustroju społeczno-gospodarczego Polski piastowskiej, wyd. W. Bukowski, t. 3, Kraków - Warszawa 2010, s. 64-65 [pierwodruk: Roczn. Hist. 41 (1975)].
} 
wczesnopiastowskiej można chyba powiedzieć, że miała ona cechy długiego trwania. Oznacza to, że oprócz środków siłowych, władza pierwszych Piastów znalazła wyraz, który uczynił ją nie tylko możliwą do sprawowania, ale i uznawaną ${ }^{114}$. Rodzi to pytanie o wzorce sprawowania władzy: czy można mówić wyłącznie o transferze i recepcji wzorców zewnętrznych, czy także o wykorzystaniu jeszcze plemiennych wzorców relacji, czy też o konwergencji, względnie przenoszeniu wzorców sprawowania władzy wypracowanych w trakcie podboju na kolejne opanowywanie terytoria i grupy ludzi? Prawdopodobnie mamy tu do czynienia z połączeniem tych procesów: system świadczeń i danin oraz podstawowej jurysdykcji musiał przynajmniej częściowo odwoływać się do zakorzenionych w zwyczaju procedur, by w ogóle móc funkcjonować. Przykładem może być choćby budowa czy naprawa grodów, które przecież wznosiły także plemiona, a przedsięwzięcie takie wymagało nie tylko umiejętności i organizacji technicznej, ale i znaczącej kontynuacji wykonywania władzy oraz uznawania tej władzy zdolnej zarządzić pewne prace i kierować nimi, zatem systemu akceptowanych świadczeń, obowiązków, tym samym systemu władczego. Do pewnego stopnia eliminowało by to zatem pewne milczące, lecz chyba błędne założenie, że z władzy militarnej wywodziła się każda inna - w tym jurysdykcyjna i fiskalna. Budowa monarchii wczesnopiastowskiej była zatem procesem budowy, adaptacji i przekształcania zwyczaju, tj. tutaj więzi i instytucji społecznych, łączących władcę z elitą oraz poddanymi. Karol Buczek był np. zdania, że pewne monopole monarsze mogły istnieć już uprzednio, wykonywane przez arystokrację plemienną - co może być przypuszczalnie prawidłowym podejrzeniem co do tego, jak mogły funkcjonować plemienne jeszcze systemy obowiązków czy trybutarne ${ }^{115}$. Wydaje się, że budowie struktur władzy towarzyszyło również przeorganizowanie więzi społecznych, by służby zaadoptowane lub narzucone ad hoc dla potrzeb ogniw monarchii utrwalić, czyniąc z nich zwyczaj - jak? Odniósłszy je do grupowego statusu - tj. zespołu reguł kształtujących relacje grupy poddanych i monarchy - do ludzi je wykonujących. Można było wówczas ten wzorzec powielać, tworząc nadto stosunki budujące relację władzy. Być może jest to jeden z mechanizmów pojawienia i utrwalenia się - jak podpowiada wishful thinking badacza - starych praw grupowych (jakże przecież zróżnicowanych) ludności służebnej i prawa rycerskiego. Na dalszym planie widzimy, jak poniekąd możemy przypuszczać, starą instytucję elitotwórczą, tj. drużynę (chyba istotną tylko dla wyższego eszelonu stosunków

114 Por. K. Buczek, Egzekwowanie świadczeń publicznych, s. 229, 234-237.

115 K. Buczek, Targi, s. 26-27, 31. 
władczych), ale i domniemany transfer oraz recepcję pewnych wzorców ottońsko-salickich, czy późniejszych Rzeszy XII w. - które najwyraźniej dotknęły tego, co najłatwiej było panującemu narzucić: ceremonialnej komunikacji w sferze publicznej (tj. aktów władczych), formy i hierarchii elity władzy, w tym także - hierarchii, w którą uszeregowano ludzi, a także instytucje organizacji grodowej.

Nadesłany: 6 I 2018

Nadesłany po poprawkach recenzyjnych: 14 III 2018

Zaakceptowany: 15 III 2018

dr Franciszek Dąbrowski

Wydział Bezpieczeństwa Narodowego

Akademia Sztuki Wojennej

al. Chruściela 103 bl. 25

00-910 Warszawa-Rembertów

f.dabrowski@akademia.mil.pl

Instytut Pamięci Narodowej

Komisja Ścigania Zbrodni przeciwko Narodowi Polskiemu

ul. Wołoska 7

02-675 Warszawa

franciszek.dabrowski@ipn.gov.pl

\section{Strongholds as power institutions in the early-Piast monarchy (in written sources)}

Paper summarizes selected source information concerning strongholds as power institutions of Polish monarchy in $10^{\text {th }}-12^{\text {th }} \mathrm{c}$. AD: forged foundation diploma for Mogilno Benedictine abbey (with date 1065), papal bullae for Gniezno, Włocławek, Wrocław and Kraków dioceses, and relevant fragments of Gallus Anonymus and Magister Vincentius chronicles. Author considers the power system in the $10^{\text {th }}-12^{\text {th }}$ centuries' Poland as a concise of relationships between rulers and commoners, based on the legal status of social groups as milites and peasants, and territorial governance located in strongholds (with fiscal, military and supposedly judicial competences). 